\title{
How Effective are Macroprudential Policies? An Empirical Investigation
}

Akinci, Ozge and Olmstead-Rumsey, Jane

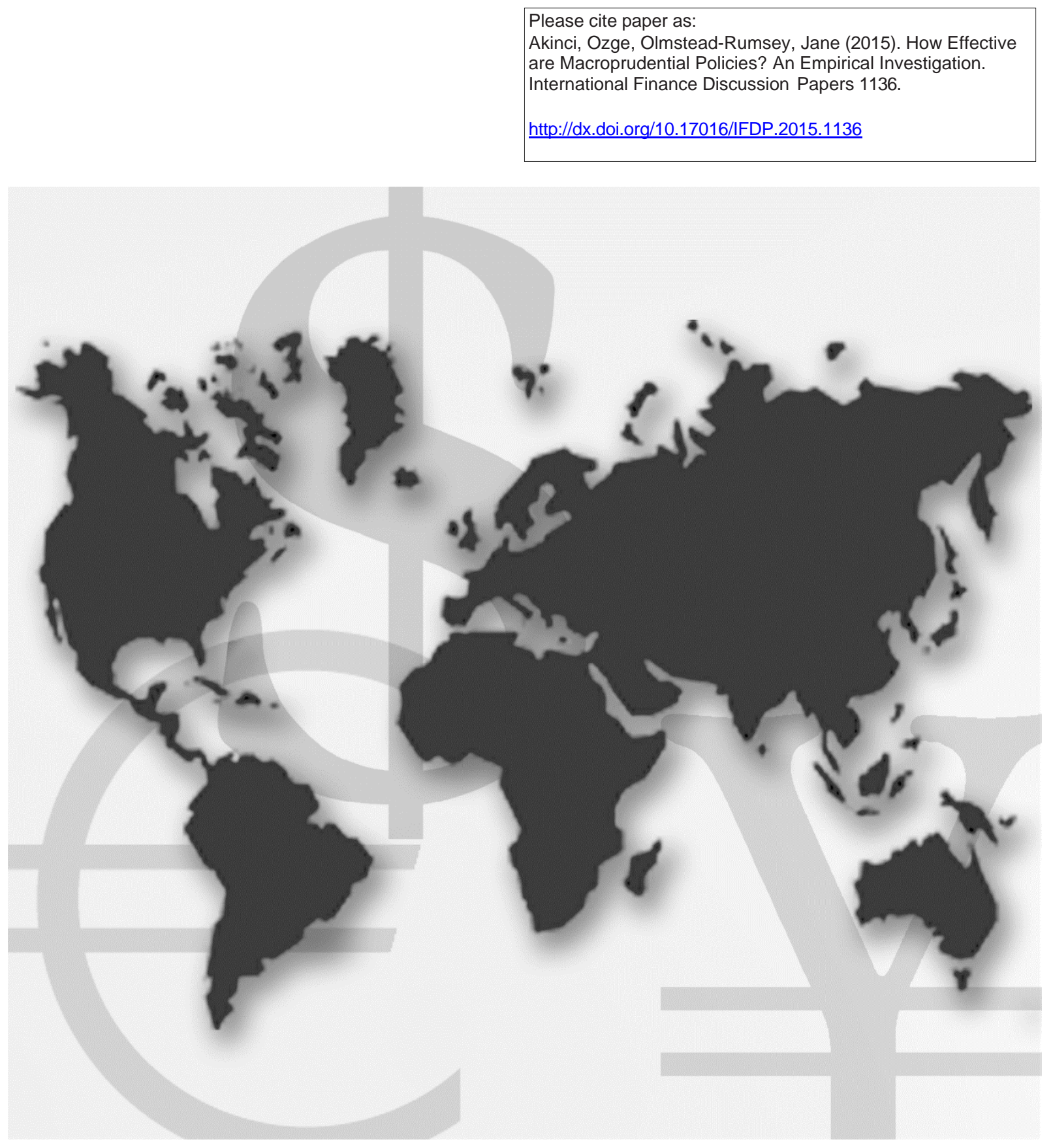

\section{International Finance Discussion Papers}

Board of Governors of the Federal Reserve System

Number 1136

May 2015 
Board of Governors of the Federal Reserve System

International Finance Discussion Papers

Number 1136

May 2015

\title{
How Effective are Macroprudential Policies? An Empirical Investigation
}

\author{
Ozge Akinci and Jane Olmstead-Rumsey
}

NOTE: International Finance Discussion Papers are preliminary materials circulated to stimulate discussion and critical comment. References to International Finance Discussion Papers (other than an acknowledgment that the writer has had access to unpublished material) should be cleared with the author or authors. Recent IFDPs are available on the Web at www.federalreserve.gov/pubs/ifdp/. This paper can be downloaded without charge from the Social Science Research Network electronic library at www.ssrn.com. 


\title{
How Effective Are Macroprudential Policies? An Empirical Investigation*
}

\author{
Ozge Akinci and Jane Olmstead-Rumsey ${ }^{\dagger}$
}

June 1, 2015

\begin{abstract}
In recent years, policymakers have generally relied on macroprudential policies to address financial stability concerns. However, our understanding of these policies and their efficacy is limited. In this paper, we construct a novel index of domestic macroprudential policies in 57 advanced and emerging economies covering the period from 2000:Q1 to 2013:Q4, with tightenings and easings recorded separately. The effectiveness of these policies in curbing bank credit growth and house price inflation is then assessed using a dynamic panel data model. The main findings of the paper are: (1) Macroprudential policies have been used far more actively after the global financial crisis in both advanced and emerging market economies. (2) These policies have primarily targeted the housing sector, especially in the advanced economies. (3) Macroprudential policies are usually changed in tandem with bank reserve requirements, capital flow management measures, and monetary policy. (4) Empirical analysis suggests that macroprudential tightening is associated with lower bank credit growth, housing credit growth, and house price inflation. (5) Targeted policies - for example, those specifically intended to limit the growth of housing credit - seem to be more effective. (6) In emerging economies, capital inflow restrictions targeting the banking sector are also associated with lower credit growth, although portfolio flow restrictions are not.
\end{abstract}

Keywords: Bank Credit, House Prices, Macroprudential Policy, Dynamic Panel Data Model JEL classification: E32, F41, F44, G15

*Thanks to Shaghil Ahmed, Mark Carey, Stijn Claessens, Brahima Coulibaly, Ricardo Correa, Neil Ericsson, Steven Kamin, Luis Serven, Albert Queralto, John Rogers and seminar participants in the Federal Reserve Board International Finance Workshop, 6th BIS CCA Research Conference, and George Washington University for helpful comments and suggestions. Thanks to Ivo Krznar for sharing the IMF macroprudential survey results database and to Shaghil Ahmed and Andrei Zlate for sharing their capital control index data with us. The views expressed in this paper are solely the responsibility of the authors, and should not be interpreted as reflecting the views of the Board of Governors of the Federal Reserve System or of any other person associated with the Federal Reserve System.

${ }^{\dagger}$ Board of Governors of the Federal Reserve System, Division of International Finance, 20th St and Constitution Ave NW, Washington, DC, 20551, USA. Contact at ozge.akinci@frb.gov, jane.m.olmsteadrumsey@frb.gov. 


\section{Introduction}

In recent years, many countries have experienced boom-bust cycles in credit and asset prices, some of which resulted in severe financial crises. In response to these cycles, authorities in many countries have implemented macroprudential policies as a first line of defense against financial instability risks. ${ }^{1}$ Examples of the macroprudential tools employed are countercyclical capital requirements, dynamic loan-loss provisioning, credit growth limits in specific sectors, and time-varying loan-to-value (LTV) or debt-to-income ratio (DTI) caps for loans.

Even though macroprudential policies have been used intensively in recent years, our understanding of these policies and their efficacy is limited. This paper focuses on cyclical risks that are primarily associated with elevated asset prices and excessive credit growth and makes three contributions to the literature: First, it develops a new set of indexes of macroprudential policies in 57 advanced and emerging countries covering the period from 2000:Q1 to 2013:Q4. Second, it documents how these macroprudential policy indexes are correlated with other policy measures, such as monetary policy and capital flow management policies. Third, it uses these indexes in a dynamic panel data model to investigate the effectiveness of macroprudential policies in restraining the growth of credit and of asset prices. The paper focuses on domestic bank credit growth, housing credit growth, and house price inflation to measure the efficacy of these macroprudential tools, given that these variables have often been the target of macroprudential policy because of their links to boom-bust financial cycles. ${ }^{2}$

Several macroprudential policy indexes are constructed in this paper for different types of macroprudential policy tools (e.g. capital requirements, dynamic loan-loss provisioning, caps on LTV or DTI ratios) as well as an aggregate index, with tightening and easing actions in a given month coded separately. The aggregate index used in the baseline dynamic panel data model characterizes the macroprudential policy stance in each country by cumulating the number of tightenings net of easings since 2000. The dependent variables (quarterly growth rate of real bank credit, real housing credit, and real house prices) are regressed on various indexes of macroprudential policy and on control variables, including real GDP growth, the change in the nominal monetary policy rate, and a global risk aversion variable proxied by the VIX.

\footnotetext{
${ }^{1}$ Prior to the global financial crisis, the general consensus was that monetary policy was not well-suited to address financial stability concerns. Since the crisis, many policymakers remain reluctant to shift monetary policy away from targeting core macroeconomic objectives such as inflation and output stabilization, preferring to retain monetary policy as a last line of defense against financial instability risks, with cyclical macroprudential tools constituting the first line of defense.

${ }^{2}$ Recent literature, for example, Schularick and Taylor (2012), Gourinchas and Obstfeld (2012) and Mendoza and Terrones (2012), suggests that credit and asset price boom events often end up with financial crises.
} 
The main findings of the paper are: (1) Macroprudential policies have been used far more actively after the global financial crisis in both advanced and emerging market economies, with the number of tightening actions significantly outweighing the easing actions in the last decade. (2) These policies have primarily targeted the housing sector, especially in the advanced economies. (3) Macroprudential policies are usually changed in tandem with bank reserve requirements, capital flow management measures, and monetary policy. (4) Empirical analysis suggests that macroprudential policy variables exert a statistically significant negative effect on bank credit growth and house price inflation. (5) Targeted policies, which are specifically intended to limit the growth of credit in a certain sector, seem to be more effective. For example, we find that the negative effect of the macroprudential policy variables on housing loans and house price inflation is driven entirely by measures directed at the housing market. (6) In emerging economies, capital inflow restrictions targeting the banking sector are associated with lower credit growth, although portfolio flow restrictions are not. The effects of macroprudential policy measures are economically significant as well. Our counterfactual exercise reveals that if the authorities had not used these measures, average credit growth and house price inflation in these countries would have been significantly higher. These results are also robust to several extensions of the empirical specification.

This paper is related to a growing body of empirical research on financial stability. Recent evidence about the effectiveness of macroprudential policy is mixed and still preliminary. Most empirical work on the subject relies on the 2011 IMF survey data presented in Lim et al. (2011). Using this database, Lim et al. (2011) find that several different macroprudential tools reduce the procyclicality of credit growth by reducing the correlation between credit growth and GDP growth. IMF (2012) explores the relationship between monetary and macroprudential policies using the same IMF survey. Focusing on capital requirements, reserve requirements, and LTV and DTI caps, that paper finds that capital requirements and reserve requirements constrain credit growth but that the effects differ in credit busts versus credit booms for capital requirements. By reviewing case studies, DellAriccia et al. (2012) find that some macroprudential policies can help soften the blow of financial crises.

Although our database suggests that the use of macroprudential policy measures has increased significantly in the past three years, only a few papers use more recent data on these tools. For example, Cerutti et al. (2015a) uses a 2013 IMF survey to create an annual dataset of macroprudential policies in 119 countries. This dataset records, for each year, whether different types of policies were in place, without capturing if and when the instrument was adjusted. They find that an index summing all the different types of policies is correlated with lower credit growth, especially in emerging market economies. Another recent paper by Bruno et al. (2014) also uses the Bank for International Settlements (BIS) macroprudential 
policy database and a database of capital flow management policies to study the effects of these policies on credit, banking flows, and bond flows in 12 Asian countries. They find that monetary policy, banking inflow controls, and macroprudential policies were used as complements in Asia from 2004 to 2013 and that bank inflow controls reduced the growth of bank inflows from 2004 to 2007, but not recently.

More empirical work has been done with regard to housing markets. Several studies using panel data for different regions find that housing measures may reduce mortgage credit booms (Zhang and Zoli (2014) and IMF (2014)). Case studies from emerging Europe (Vandenbussche et al. (2012)) and Asia (Craig and Hua (2011)) show that macroprudential tools, especially housing measures, limited house price growth in those regions. On the other hand, Kuttner and Shim (2013) use the BIS database presented in Shim et al. (2013) of macroprudential measures covering as far back as 1980 for some countries. Using three different econometric techniques, they find evidence for the economic and statistical significance of DTI and housing taxes on house price inflation. LTV caps, limits on banks' exposure to the housing market, and housing taxes are also found to be significant in curbing housing credit, but only in the panel data approach. Only housing-related taxes are found to affect house price growth.

Other studies use bank-level data rather than country-level data in the empirical analysis. Such micro-level evidence is also mixed about the effectiveness of macroprudential policies: For example, Claessens et al. (2014) use bank-balance-sheet-level data to argue that credit growth declines when credit growth ceilings, LTV caps, and DTI caps are put in place. Zhang and Zoli (2014) present bank-level data on 74 Asian banks in addition to their country-level data to demonstrate that macroprudential policies limited the supply of credit from Asian banks. However, Aiyar et al. (2014) use bank-level data from the UK to show that bank capital requirements were somewhat ineffective due to increased lending (substitution) from resident foreign bank branches. Similarly, Acharya (2013) finds that risk weights imposed to achieve macroprudential goals can perversely lead to the buildup of financial risks because risk weights on certain asset classes - such as mortgages - encourage the buildup of exposure to other assets that are not deemed as risky, but that can contribute to vulnerability after such concentrated exposure.

The literature has evidently not reached a consensus about which policies, if any, are effective. Our panel dataset - which includes a variety of advanced and emerging markets, a longer history than most studies, and the recent period in which macroprudential policy use has become much more common - allows us to evaluate these policies with a great deal of breadth and depth. To our knowledge, this is the first paper that uses a systematically created database that is based on a comprehensive set of sources: surveys conducted by the IMF, a BIS database, and feedback from national central banks and financial stability authorities. 
Moreover, we study the effect of macroprudential policies on general credit conditions, as well as more specifically on housing credit and house prices. Finally, we also consider some other aspects of countries' policy toolkits - such as different types of capital controls - that might be relevant, especially in emerging market economies, for achieving financial stability objectives.

The remainder of the paper is organized as follows: Section 2 explains in detail our macroprudential policy database and the construction of the macroprudential policy indexes. It also analyzes the incidence and evolution over time of the use of macroprudential measures in our sample and documents how domestic macroprudential policies are used in conjunction with other policies that affect credit conditions. Section 3 discusses the Korean experience with the use of macroprudential instruments as a typical case and analyzes the effectiveness of these instruments using an event study methodology. Section 4 presents the empirical model and panel estimation results. Section 5 discusses various robustness checks, and section 6 concludes.

\section{Macroprudential Policy Measures}

This section describes in detail our macroprudential policy tools database and the construction of the macroprudential policy index. The use of macroprudential policies over time and across advanced economy and emerging market economy groups is also reviewed. ${ }^{3}$

\subsection{Data}

The first step in our analysis is to build a database of macroprudential measures. To do this, we relied on national sources wherever possible. A starting point for our database was the 2011 IMF survey database on macroprudential measures presented in Lim et al. (2011). We also supplemented our database using the publicly available macroprudential database presented in Shim et al. (2013). We used national sources and a 2013 IMF survey called Global Macroprudential Policy Instruments (GMPI) to update our database through 2013. We also cross-checked our database against a cross-country database by Cerutti et al. (2015a) and Cerutti et al. (2015b), as well as the IMF's GMPI survey for a comparison of the historical data. Our database covers the period from 2000:Q1 to 2013:Q4.

This paper focuses on seven categories of macroprudential tools. Three are targeted at the housing market. The first, caps on LTV ratio for mortgage loans, restrict the amount of the loan to a certain fraction of the total value of the property. In our sample, LTV caps imposed

\footnotetext{
${ }^{3}$ For a description of the country classifications into advanced and emerging economies see Appendix A.
} 
by the authorities range from 40 percent to 95 percent. More than half the countries in our sample have used LTV caps to limit mortgage lending since 2000, making LTVs the most commonly used macroprudential tool in our sample. Another way to prohibit risky lending is to implement a cap on the DTI of the borrower - that is, to restrict the value of the borrower's debt relative to monthly income. The third category of housing measures considered is not so easily classified: We refer to these tools as "other housing measures," which can include higher regulatory risk weights for mortgage loans, quantitative limits on mortgage lending, property gains taxes, and stricter requirements for mortgage borrower credit-worthiness, among others.

We also examine four broader measures to limit credit growth targeted at banks' balance sheets. Countercyclical capital requirements (CCR) are one such tool. In this category, we include countercyclical capital buffers, increases in risk weights used to determine banks' capital adequacy ratios (excluding those on mortgage loans), capital surcharges for banks, and limits on profit distribution. A second measure targeted at banks' balance sheets is dynamic loan loss provisioning, which requires banks to set aside reserves in case of borrower default (we include specific provisioning requirements on housing loans in the "other housing category"). A third is consumer loan limits, such as stricter requirements for the creditworthiness of credit card holders. The final macroprudential measure we consider in this category is ceilings on credit growth.

\subsection{Construction of Macroprudential Policy Variables}

This paper constructs three aggregates indexes of macroprudential policy actions based on these seven tools. For each of the seven policy measures, i.e. caps on LTV and DTI ratios, other housing measures, capital requirements, provisioning, credit growth limits, and consumer loan limits, we create a dummy variable assigned a value of positive one if the measure was used to restrict credit growth or asset price growth and a value of negative one if the measure loosened macroprudential restrictions. If no action was taken in a given month, we assigned the variable a value of zero. While we typically know the month of implementation for each macroprudential action taken, we aggregate the tools to a quarterly frequency to match the frequency of our dependent variables. If a tool was used more than once in a quarter, we sum all changes over the quarter.

Ideally, we would like to measure the intensity of macroprudential policies. For example, for LTVs we would like to use the actual percentage requirement (e.g. that the LTV cap was lowered from 70 percent to 60 percent), but obtaining the level of the LTV cap is more difficult than it seems. In countries like Korea and Hong Kong, which have used LTV caps actively, different borrowers face different LTV caps based on where the property is located, 
whether it is the borrower's first or second home, and how expensive the home is. It is not straightforward, then, to record the overall LTV cap in a country, and it becomes even more difficult when comparing across countries. The same issue applies to many other types of macroprudential policies. For this reason, we chose to use indicator variables instead. ${ }^{4}$

Once we constructed the dummy variables for individual measures in each country, we were able to create cumulative indexes of housing and nonhousing measures, as well as a cumulative index for all macroprudential tools in place in a given quarter (hereafter referred to as the MAPP index). These cumulative variables sum the dummy variables (tightenings net of easings) to get an idea of a country's "macroprudential policy stance" in a given quarter (see figure 1). We use cumulative indexes in our analysis rather than the quarterly changes because it is difficult to know when macroprudential regulations impose binding constraints on borrowers and lenders - for example, an LTV cap could become binding several quarters after it is imposed, depending on financial conditions.

The housing index (MAPPH) sums the cumulative variables for the LTV, DTI, and other housing measure categories. CCRs that target the housing sector (most commonly risk weights on mortgage loans) are included in "other housing", as are loan loss provisioning requirements for mortgage loans. The nonhousing index (MAPPNH) includes CCR (excluding risk weights on housing loans), provisioning (excluding specific provisions for housing loans), credit growth limits, and consumer loan limits. Summing the housing and nonhousing indexes yields the overall MAPP index.

By summing the cumulative indicator variables for each individual measure to create the overall MAPP index, we implicitly assign each of the seven macroprudential measures equal weight in the index. Since it seems plausible that introducing or adjusting some types of measures may constitute more significant tightenings of financial conditions than others, in the robustness analysis (section 5.1) we find that this weighting is appropriate.

The evolution of individual macroprudential measures introduced in each quarter along with the cumulative MAPP, MAPPH, and MAPPNH indexes are shown in figure 1 for selected countries. The Canadian and Indian cases demonstrate that macroprudential measures, once introduced, may be adjusted several times over the sample period, with both tightening and easing actions being taken. The Swiss National Bank started to use macroprudential tools only after the global financial crisis, as the Swiss housing sector rebounded quickly while the overall economy was stagnant for a longer period. Faced with signs of overheating in the

\footnotetext{
${ }^{4}$ In fact, given that the use of indicator variables imperfectly measures magnitude of the policy changes and such measurement error will create attenuation bias for the coefficient estimates on the MAPP variables, we should be especially encouraged if we find a significant relationship between these indicator variables and credit or house price growth despite the measurement error. The fact that we do not know whether the instrument is binding or not also creates attenuation bias.
} 
Figure 1: New and Cumulative MAPP Tools in Selected Countries, 2000:Q1 to 2013:Q4

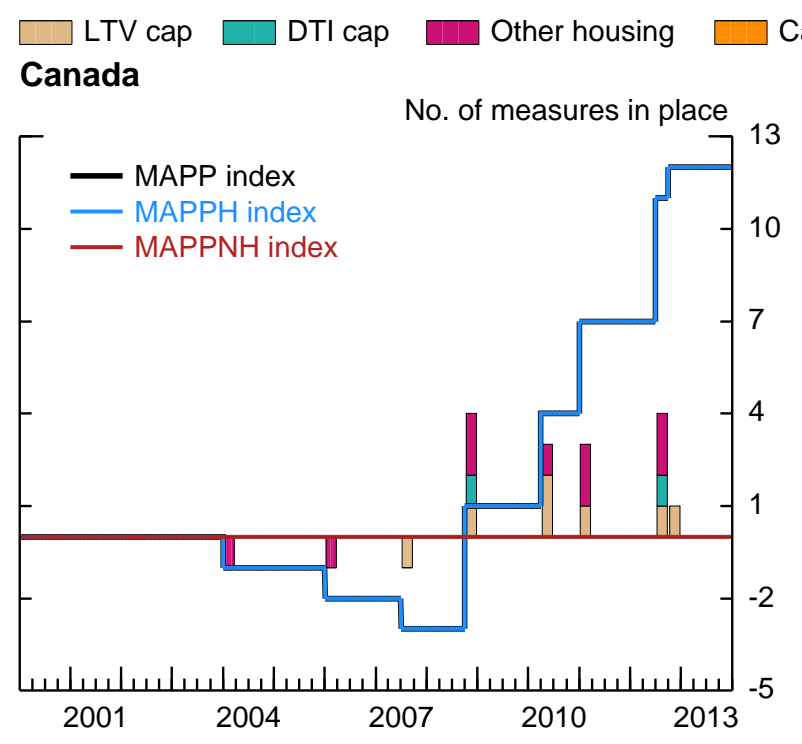

Capital requirements Provisioning

\section{Switzerland}

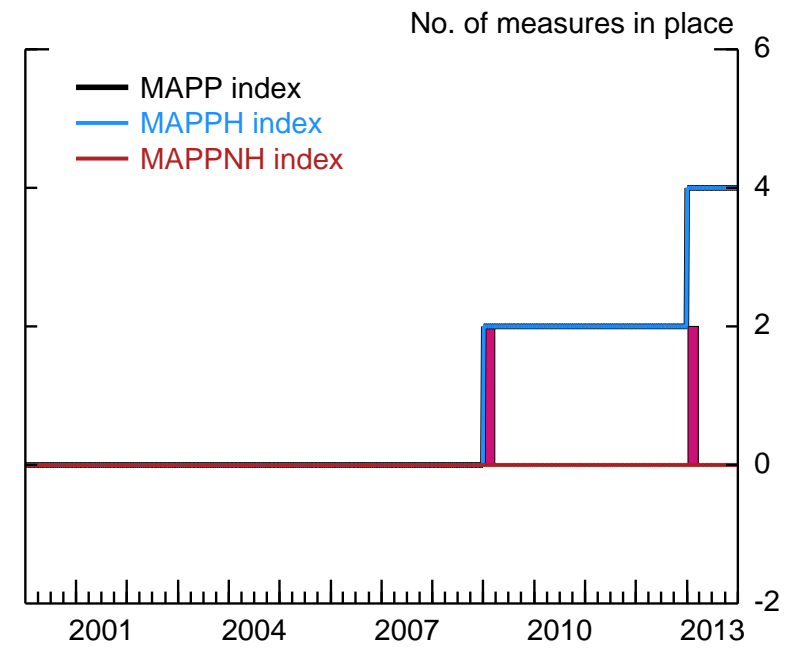

\section{Brazil}

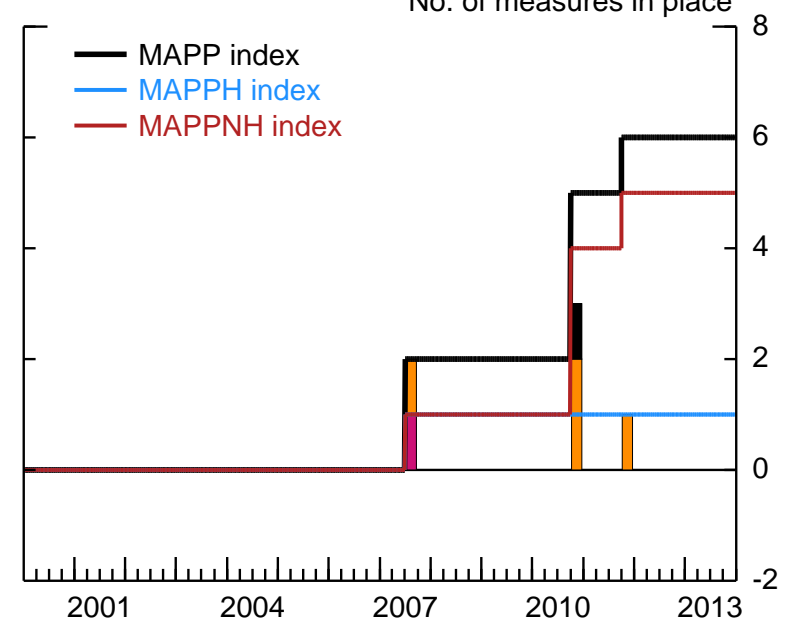

India

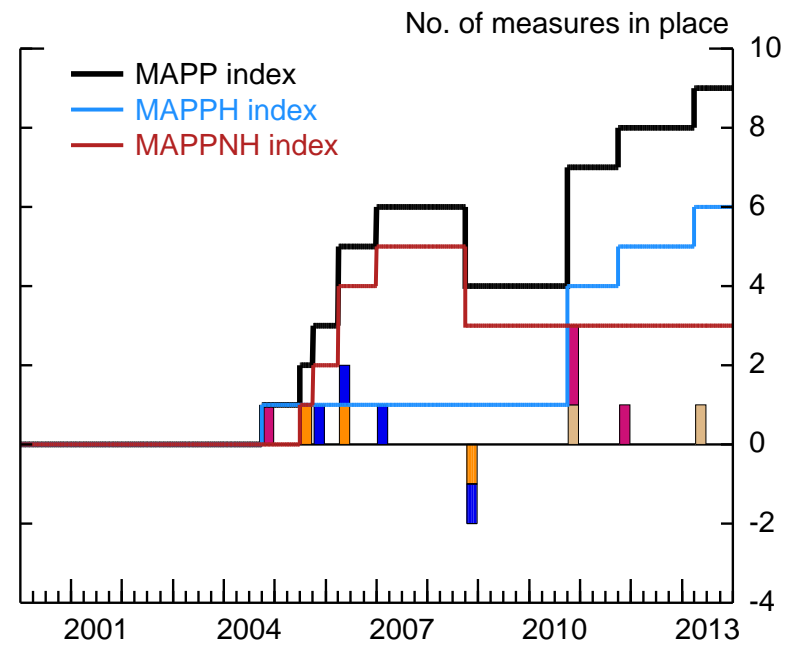

Note: Figures show the cumulative macroprudential policy index (MAPP index, black line), subindex for housing-related prudential policies (MAPPH index, blue line), and subindex for nonhousing measures (MAPPNH index, red line) for four selected countries from 2000 to 2013. The colored bars show the quarter of implementation of individual new measures. Tightenings take a positive value and loosenings take a negative value. Capital requirements and provisioning bars exclude housing-related capital requirement and provisioning measures.

housing sector, and having already increased the bank capital risk weights for high LTV loans, Switzerland activated a countercyclical capital buffer that adds 1 percentage point of capital requirement for direct and indirect mortgage-backed positions secured by Swiss residential property. In Canada, too, macroprudential actions were taken to contain a run-up in house prices and to improve resilience in the event of a housing price decline. Brazilian authorities also implemented a range of macroprudential measures, which were often accompanied by 
capital control measures (not shown).

\subsection{Usage of Macroprudential Policies}

To better understand what sort of macroprudential tools have been most popular, figure 2 shows the total incidence from 2000 to 2013 of each of the five most commonly used tools we study. ${ }^{5}$ LTV caps on housing loans were the most commonly used macroprudential tool, though capital requirements and other housing measures were also popular. It should be noted that risk weights on housing loans, a type of CCR, are by far the most common "other housing" measure in our sample and are included only in the housing macroprudential category in figure 2. DTI caps and loan-loss provisioning requirements were less popular but nonetheless were each used more than 40 times (when counting tightenings and easings) since 2000. It is clear from this figure that tightenings were much more common than easings across all macroprudential tools.

Figure 2: Use of Various MAPP Tools, 2000:Q1 to 2013:Q4

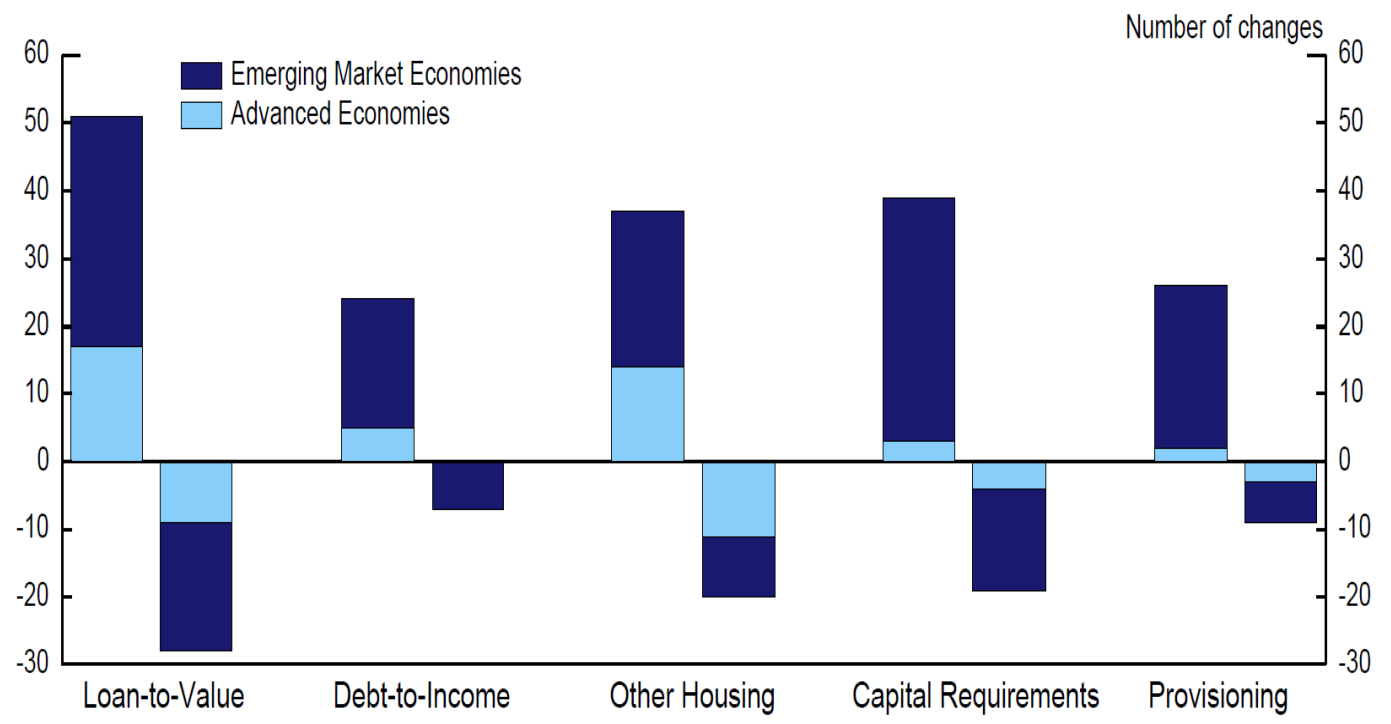

Note: The dark blue bars show the total number of each of the five most common macroprudential instruments summed across all emerging market economies in our sample for the period 2000 to 2013 . The light blue bars indicate the number of measures of each type used by advanced economies over the same period. Positive values indicate tightenings and negative values indicate loosenings of macroprudential regulations. Capital requirements and provisioning exclude housing-related measures.

Figure 3 shows the evolution of macroprudential measures introduced in each quarter across the 57 countries in our sample from 2000 to 2013 compared with average credit growth and house price inflation. Macroprudential policies have been used far more actively since the global financial crisis of 2008 compared with the pre-crisis period despite the fact that real

\footnotetext{
${ }^{5}$ Because credit growth and consumer loan limits were used sparingly, we do not show them in the figure.
} 
credit growth and real house price inflation were more pronounced in the periods preceding the global financial crisis. ${ }^{6}$ Moreover, housing measures have been much more widely used than nonhousing measures, particularly since the crisis, as housing markets in many countries recovered more quickly than the overall economy and began to overheat in some cases. It appears that policies were tightened during credit and house price booms and loosened when growth in these two variables slowed. Overall, tightenings have been much more common than easings. The largest number of easings came during the global financial crises when countries sought to encourage lending, suggesting that macroprudential tools are being used in a countercyclical manner.

Figure 4 shows macroprudential policy use and average credit and house price growth for advanced and emerging economies separately. It reveals that nearly all of the measures used in the advanced economies targeted the housing sector rather than more general credit conditions. Interestingly, macroprudential policies have been used far more actively in this group after the global financial crisis compared with the pre-crisis period, despite the fact that real credit growth and real house price growth have been relatively subdued in advanced economies, on average, since the crisis. This is partly because macroprudential tightening has been concentrated in a few advanced economies - especially Canada, New Zealand, and Switzerland - where housing markets remained robust. But this tightening may also have been motivated by increased awareness of macroprudential measures combined with concerns about the potential effects on financial markets of extended periods of ultra-low interest rates.

In emerging market economies, credit growth has been a bigger concern than house prices, and thus nonhousing measures have been used more frequently. As shown in panel B of figure 4, the use of macroprudential measures increased after the global financial crisis in emerging economies as well. But the reasons for this activity are likely somewhat different from those motivating most of the advanced economies. Speedy economic recovery in emerging economies, combined with accommodative monetary policies in advanced economies, attracted capital inflows, contributing to some of the rebound in credit growth and house prices that occurred after the global financial crisis. With output quickly going above potential for several emerging economies, significant monetary tightening might have been warranted, but fears that such tightening would exacerbate capital inflows and currency appreciation likely motivated a heavier reliance on macroprudential tightening instead.

\footnotetext{
${ }^{6}$ Many observers are concerned that macroprudential policies may be implemented in the middle of credit booms and thus a positive relationship between credit growth and macroprudential policies - the so-called endogeneity bias - might occur. This figure indicates that macroprudential polices were in part implemented in response to the global financial crisis after which credit growth has been relatively muted.
} 
Figure 3: Evolution of MAPP Use, 2000:Q1 to 2013:Q4

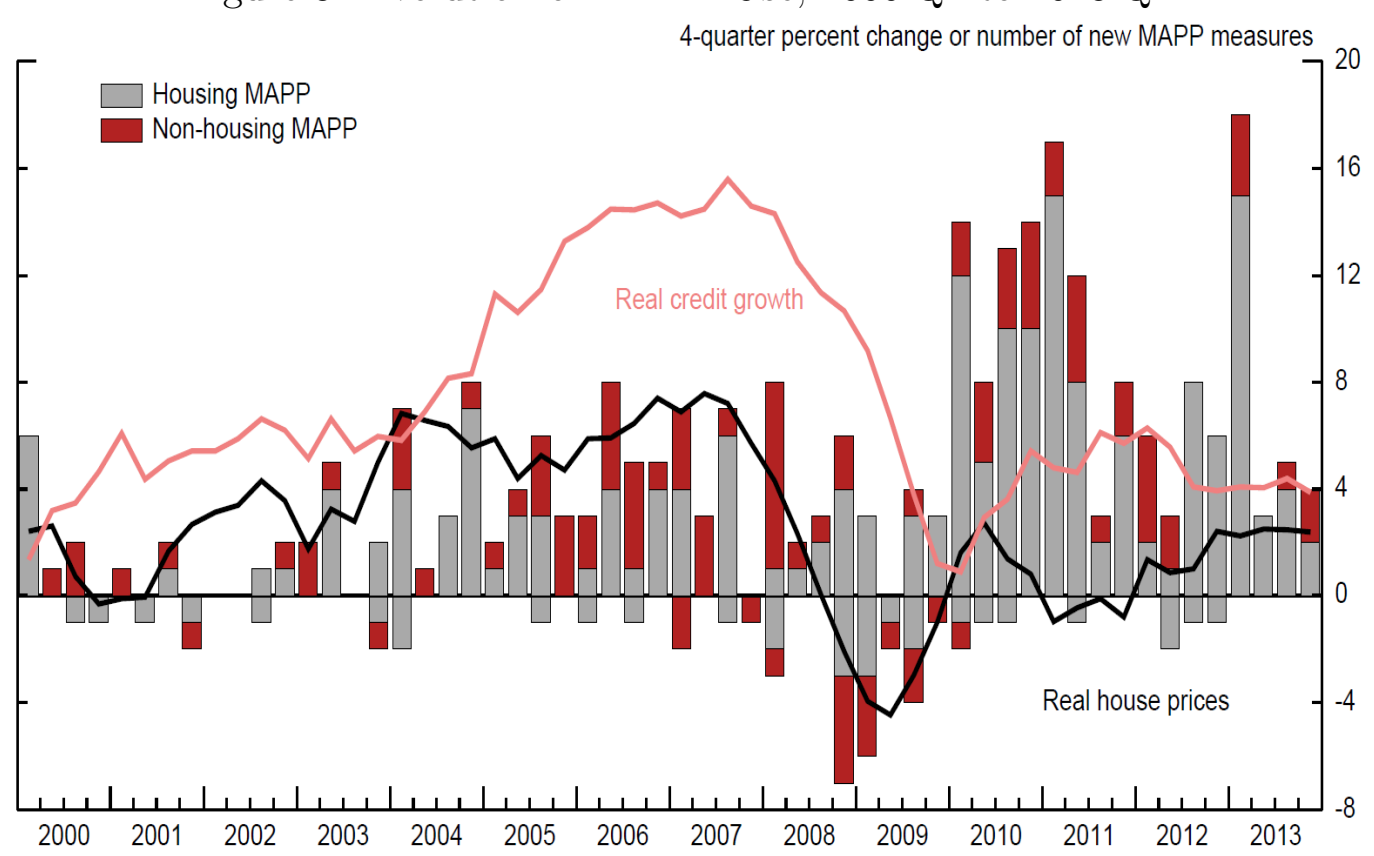

Note: The figure shows average real credit growth (pink line) and average real house price inflation (black line) across all countries. The red bars (gray bars) show the total number of new housing-related measures (nonhousing-related measures) introduced by all countries in our sample in each quarter. Positive values indicate tightenings and negative values indicate easings.

Figure 4: Evolution of MAPP Use in Advanced and Emerging Economies, 2000:Q1 to 2013:Q4

\section{A. Advanced Economies}

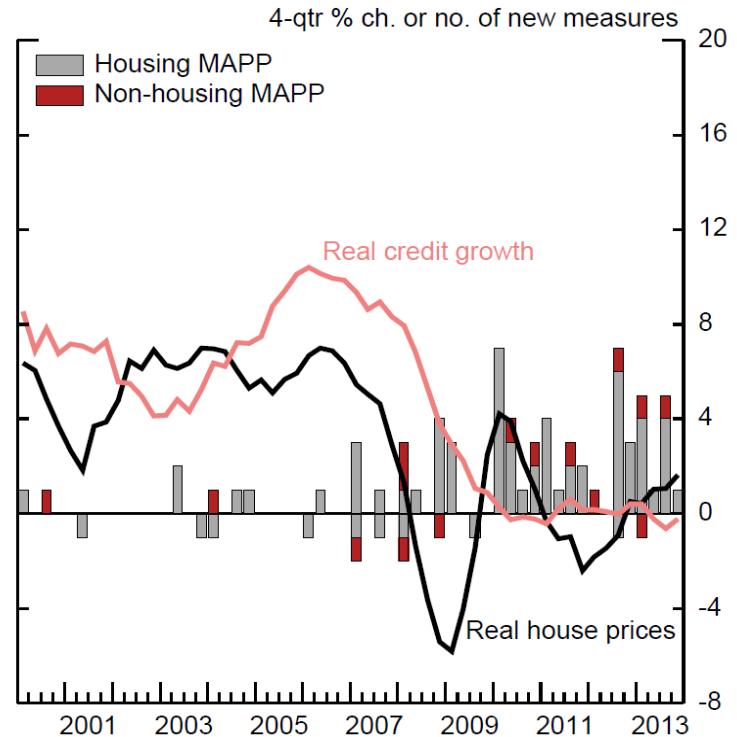

\section{B. Emerging Economies}

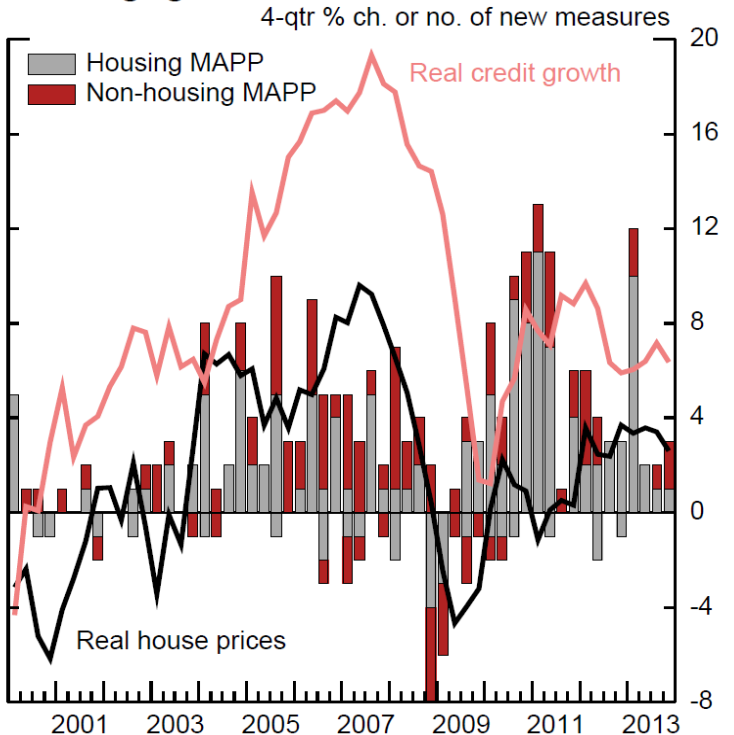

Note: The figure in panel A (panel B) shows average real credit growth and average real house price inflation across advanced economies (emerging economies). The red bars in panel A (panel B) show the total number of new housing-related measures introduced by advanced economies (emerging economies) in our sample in each quarter. The gray bars show the same information for nonhousing measures. 


\subsection{Macroprudential Policy as Part of the Policy Toolkit}

The goal of this section is twofold. First, it studies how much various types of domestic macroprudential policies are synchronized with one another. Second, it explores how the use of domestic macroprudential measures is correlated with other policy actions that may affect credit growth and asset price inflation. Such policy actions include monetary policy rate changes and changes to reserve requirements on domestic currency deposits as well as capital flow restrictions. We find that individual macroprudential measures were often used together. We also document that macroprudential policies are usually changed in tandem with bank reserve requirements, capital flow management measures, and monetary policy.

Data on domestic currency reserve requirements comes from Cordella et al. (2014). Our data for capital flow measures come from Ahmed and Zlate (2014) and cover 19 emerging market economies from 2002-2012. These quarterly, cumulative capital control indexes were constructed using information from the IMF's Annual Report on Exchange Arrangements and Exchange Restrictions (AREAER) database. $^{7}$ In contrast to the IMF capital control indexes based on the AREAER database, these indexes seek to capture some of the intensity of capital controls by changing as measures are adjusted, not just when they are created or eliminated. All three indexes focus exclusively on restrictions on inflows. The overall capital control index cumulates restrictions on foreign direct investment, portfolio investment (divided into bond and equity restrictions), and banking investment into the country. The banking subcomponent includes measures such as taxes on short term external borrowing, quantitative limits on banks' foreign exchange exposure, and reserve requirements on foreign exchange liabilities. We focus on the banking inflow restrictions and the portfolio inflow restrictions in addition to the overall capital control index because these measures are most likely to affect bank credit growth.

Table 1 shows pairwise correlations of the seven domestic macroprudential policy tools that we study in this paper. Individual macroprudential measures, particularly housing measures, were often used simultaneously by countries in our sample. LTV and DTI caps, in particular, are strongly positively correlated. Positive correlations among housing measures appear in the emerging and advanced economy subsamples as well. Among the measures that target the general credit conditions, capital requirements, in particular, are strongly positively correlated with all other nonhousing measures. In general, of the seven measures that we study in this paper, most are at least weakly positively correlated, with the exception of credit growth limits. $^{8}$

\footnotetext{
${ }^{7}$ These countries are: Argentina, Brazil, Chile, Colombia, Czech Republic, Hungary, India, Indonesia, Israel, Korea, Malaysia, Mexico, Philippines, Poland, Romania, South Africa, Taiwan, Thailand, and Turkey.

${ }^{8}$ We also checked that these relationships have not changed since the financial crisis. When we compare
} 
Table 1: Correlations Between Individual Measures

\begin{tabular}{lccccccc}
\hline \hline \multicolumn{1}{c}{ Variables } & LTV & DTI & Oth. Hous. & CCR & Prov. & Cons. Loan & Cred. Limit \\
\hline LTV & 1.000 & & & & & & \\
DTI & $0.595^{*}$ & 1.000 & & & & & \\
Oth. Hous. & $0.432^{*}$ & $0.255^{*}$ & 1.000 & & & & \\
CCR & $0.064^{*}$ & 0.000 & $0.040^{*}$ & 1.000 & & & \\
Prov. & $0.260^{*}$ & $0.110^{*}$ & $0.120^{*}$ & $0.239^{*}$ & 1.000 & & \\
Cons. Loan & $0.060^{*}$ & $0.055^{*}$ & $0.181^{*}$ & $0.306^{*}$ & $0.190^{*}$ & 1.000 & \\
Cred. Limit & $-0.049^{*}$ & 0.012 & 0.000 & $0.210^{*}$ & $-0.048^{*}$ & $0.113^{*}$ & 1.000 \\
\hline \hline
\end{tabular}

Note: Correlation between the cumulative indexes of seven domestic macroprudential policy tools for 57 countries from 2000 to 2013. LTV=Loan-to-value caps, DTI=Debt-to-income caps, Oth. Hous.=Other housing measures, CCR=Countercyclical capital requirements (excl. those on mortgages), Prov.=Provisioning requirements (excl. those on mortgages), Cons. Loan=Consumer loan limits, Cred. Limit=Credit growth ceilings. An * signifies the correlation is significant to the 5 percent level.

Table 2: Correlations Between MAPP and Other Policy Measures

\begin{tabular}{lcccc}
\hline \hline Variables & Housing MAPP & Nonhousing MAPP & Policy Rate & Reserve Requirements \\
\hline MAPPH & 1.000 & & & \\
MAPPNH & $0.152^{*}$ & 1.000 & & \\
Pol. Rate & $-0.055^{*}$ & $0.423^{*}$ & 1.000 & \\
Res. Req & $0.129^{*}$ & $0.133^{*}$ & $0.058^{*}$ & 1.000 \\
\hline
\end{tabular}

$\overline{\text { Note: Table showing correlation between the cumulative macroprudential policy indexes for housing measures (MAPPH) and }}$ nonhousing measures (MAPPNH), which captures the level of these measures, the monetary policy rate (Pol. Rate), and a cumulative index of reserve requirements on domestic currency deposits (Res. Req.) for 57 countries from 2000 to 2013 . An * signifies the correlation is significant to the 5 percent level.

Table 3: Correlations Between MAPP and Other Policy Measures in 19 Emerging Market Economies

\begin{tabular}{lcccccc}
\hline \multicolumn{1}{c}{ Variables } & MAPPH & MAPPNH & Bank CFM & Port. CFM & Policy Rate & Res. Req. \\
\hline MAPPH & 1.000 & & & & & \\
MAPPNH & $0.145^{*}$ & 1.000 & & & & \\
Bank CFM & 0.049 & $0.102^{*}$ & 1.000 & & & \\
Port. CFM & $-0.117^{*}$ & 0.018 & $0.541^{*}$ & 1.000 & & \\
Pol. Rate & $-0.075^{*}$ & $0.416^{*}$ & $0.131^{*}$ & 0.007 & 1.000 & \\
Res. Req & $-0.098^{*}$ & $0.244^{*}$ & -0.016 & $-0.252^{*}$ & $0.180^{*}$ & 1.000 \\
\hline
\end{tabular}

Note: Table showing correlation between the cumulative macroprudential policy indexes for housing measures (MAPPH) and nonhousing measures (MAPPNH), and cumulative indexes of capital controls from Ahmed and Zlate (2014) including portfolio inflow restrictions (Port. CFM) and banking inflow restrictions (Bank CFM), the monetary policy rate (Pol. Rate), and a cumulative index of reserve requirements on domestic currency deposits (Res. Req.) for 19 emerging market economies from 2002 to 2012 . An ${ }^{*}$ signifies the correlation is significant to the 5 percent level. 
Table 2 shows how the housing and nonhousing macroprudential policy indexes are correlated with monetary policy actions (both the policy rate and reserve requirements). It seems that policymakers generally use macroprudential policy measures and monetary policies as complements (the correlations are weakly positive), with the exception of housing-related macroprudential measures and policy rate changes, which are negatively correlated. The negative relationship is perhaps due to the fact that several countries - in particular advanced economies - have kept policy rates low since the financial crisis, and have simultaneously tightened macroprudential policies related to the housing sector in recent years. ${ }^{9}$ This finding might also reflect the difficulty faced by policymakers in dealing with housing booms using monetary policy. In contrast, the correlation between nonhousing macroprudential measures and the policy rate (as well as the reserve requirements) is quite high. Analyzing the preand post-crisis periods separately, the relationships among these measures have not changed much since the crisis.

Capital flow measures can also affect the supply of credit. Several countries used capital flow management tools - such as portfolio inflow restrictions and banking inflow restrictionsalong with macroprudential policies to deal with fast-growing bank credit. As illustrated in figure 5, Brazil, for example, has tightened macroprudential policy along with capitalin flow restrictions, especially restrictions on banking flows, from 2000 through 2012. Policy rate hikes from 2010 through mid-2011 acted to curb inflation but also tempered the rapid expansion of credit. Brazil has also used reserve requirements actively since 2000, tightening them considerably from 2004 to 2005 as well as recently in 2012. Korea, like Brazil, has employed many different policies since 2002. Banking flow restrictions (especially taxes on short-term borrowing) were incrementally tightened from 2010 through mid-2011 along with the monetary policy rate. Domestic macroprudential policy actions were mixed in this period: Some of the MAPP measures imposed earlier were reversed in 2010, but domestic macroprudential measures were tightened again in 2011 before being eased again since $2012 .{ }^{10}$ In contrast, Israel began using macroprudential and other financial stability policies only in 2010 but has tightened such policies considerably since then while keeping the policy rate low. In this respect, Israel stands out among the emerging market economies as an example where monetary policy and macroprudential policy were adjusted in opposite directions. Domestic macroprudential policies targeting the housing sector, along with capital flow measures,

2000-2008 with 2009-2013, the results are extremely similar.

${ }^{9}$ When we calculate the same correlations among measures only for advanced economies we find a much stronger negative correlation between housing measures and the policy rate.

${ }^{10}$ Brazil used an array of policies targeted on capital flows and financial stability while the measures used in Korea, in particular capital control tools such as tax on short term external borrowing, aimed at addressing vulnerabilities revealed by the sudden stop it experienced early in the global financial crisis. 
have been tightened since mid-2010, but monetary policy has been eased since late 2011 in response to slowing growth in an environment of low inflation. Finally, in Poland, authorities have tightened domestic financial conditions using macroprudential policy but have relaxed controls on inflows, reserve requirements, and monetary policy recently.

Table 3 displays the correlations between MAPP measures, capital flow measures, and monetary policy for the 19 emerging countries covered by Ahmed and Zlate (2014)'s capital flow measure database. ${ }^{11}$ Even in this subset of emerging markets, the correlations between macroprudential and monetary policy are similar to their relationship in the sample as a whole shown in table 2, which includes a mix of advanced and emerging market economies. In these 19 countries, two different types of capital controls - those on banking and portfolio inflowsare strongly positively correlated with each other. Perhaps not surprisingly, banking inflow restrictions are also positively correlated with nonhousing measures like capital requirements and credit growth ceilings, since tightening these types of measures is likely aimed at reducing bank credit growth. In a similar vein, policy rate increases and banking inflow restrictions are also positively correlated. There seems to be no clear pattern regarding the use of banking inflow restrictions and reserve requirements or housing-related measures.

\section{Event Study Analysis: The Case of Korea}

This section turns to an event study for Korea to offer some clarity about how macroprudential tools can be adjusted to address particular vulnerabilities. After the Asian crisis of the late 1990s, house prices and credit to households in Korea began to grow rapidly, starting in 2001. Since then, Korea has experienced both rapid growth and rapid slowdowns in credit and house prices. The Bank of Korea responded with measures, mostly housing-related, to attenuate these cycles. This section explores the success and lessons learned from the Korean experience with domestic macroprudential tools from 2000 to $2013 .^{12}$

At their peak in 2002, real house prices increased 15 percent compared with a year earlier (figure 6, panel A). The boom was largely concentrated in so-called "speculative zones" of Seoul, Korea's capital. In September 2002, at the height of the boom, Korean authorities capped the LTV ratio of mortgage loans from banks and insurance companies at 60 percent

\footnotetext{
${ }^{11}$ For India, we have assumed no change in capital flow measures over the sample period because the changes recorded in the Ahmed and Zlate (2014) database reflect a structural shift to greater financial openness rather than pursuit of financial stability goals.

${ }^{12}$ Korea also used other macroprudential policies to limit foreign exchange exposure during the sample period. During the 2008 financial crisis foreign bank branches and some Korean banks faced liquidity shortages as they tried to roll over their maturing short-term external liabilities but were unable to do so because of tight global financial conditions. To address the maturity and currency mismatches of these banks, Korean authorities have introduced a series of measures to limit foreign exchange exposure of banks.
} 
Figure 5: MAPP, Capital Flow Measures and Monetary Policy, 2000:Q1 to 2013:Q4

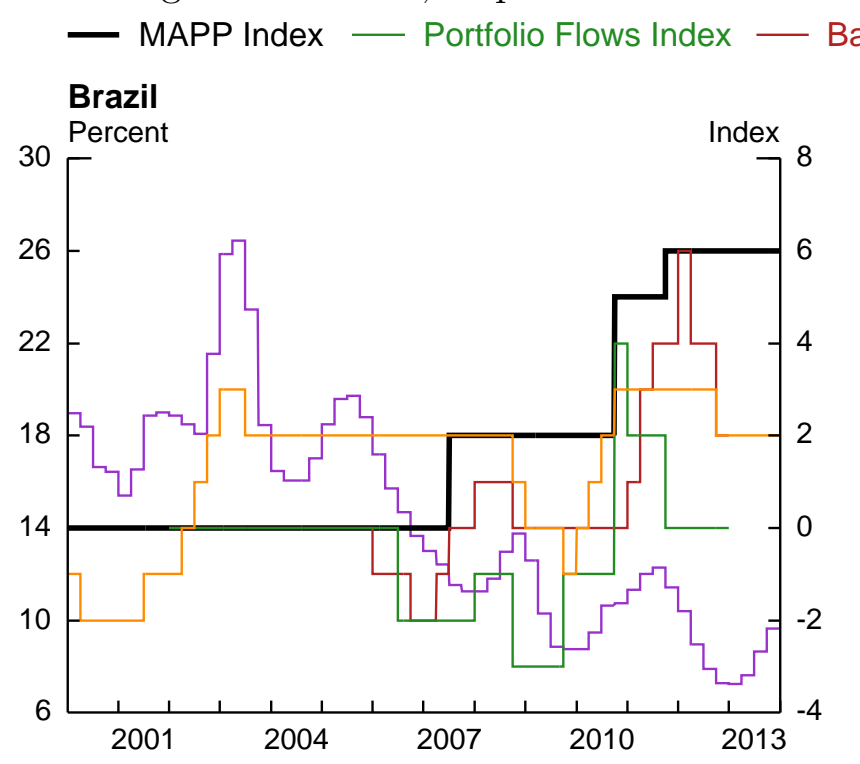

anking Flows Index — Res. Req. Index — Policy Rate
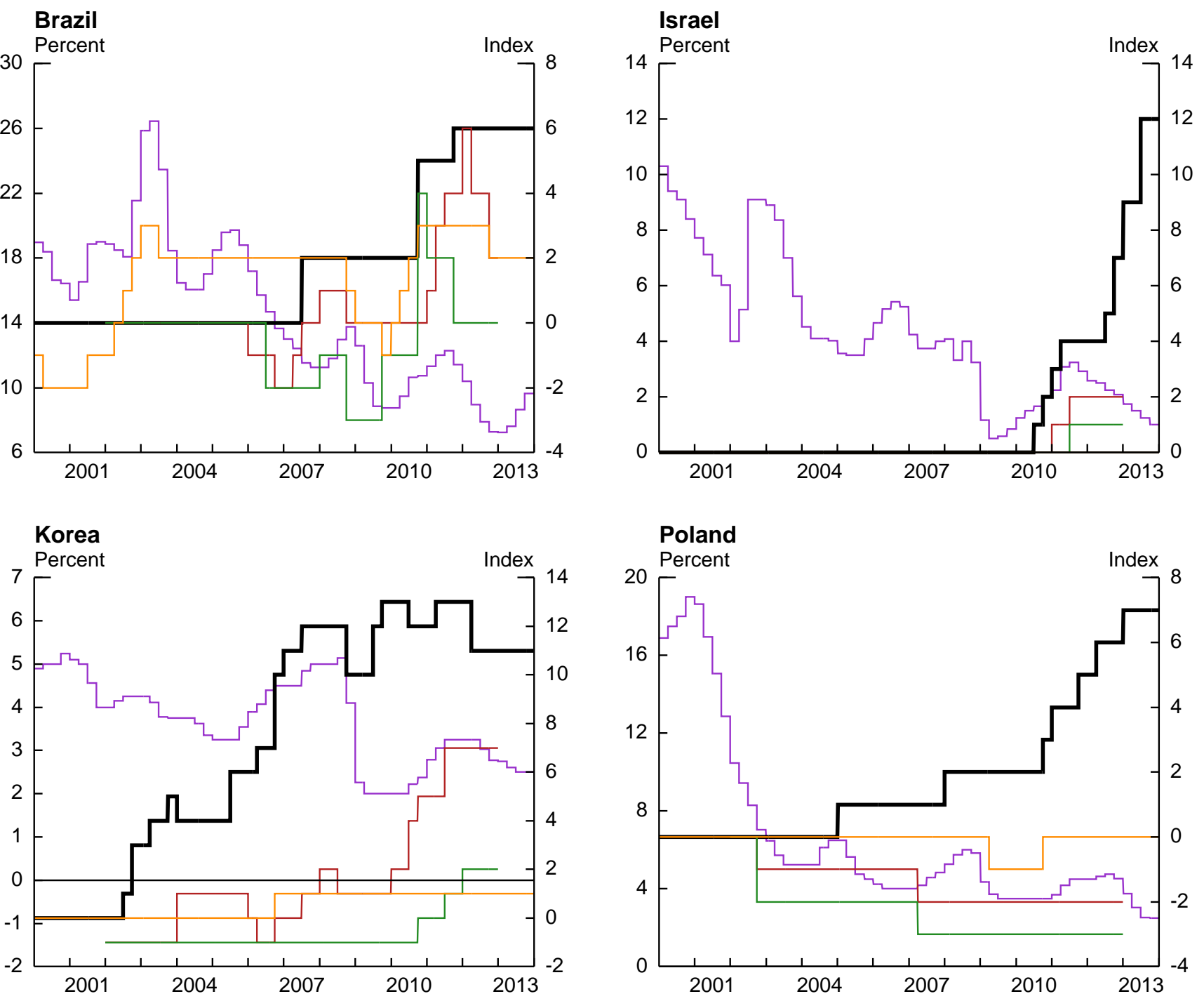

Note: Figures show the cumulative macroprudential policy index (MAPP Index, black line), portfolio inflow control index (green line), banking inflow control index (red line), domestic currency reserve requirement index (Res. Req. Index, orange line), and monetary policy rate (purple line, left axis) for four selected countries from 2000 to 2013 . Tightenings for the policy indexes take a positive value and loosenings take a negative value.

in these speculative zones. The following month authorities mandated additional loan loss provisioning for housing loans and raised the regulatory risk weights on mortgages used to calculate the capital base of banks from 50 percent to between 60 percent and 70 percent.

The LTV ratio was further tightened several times between 2002 and late 2003 before being loosened in March 2004 as credit and house price growth slowed to near zero (figure 6 , panel A). The loosening applied only to loans with maturities greater than 10 years. By 
Figure 6: Case Study: Housing Booms and Busts and Macroprudential Response in Korea

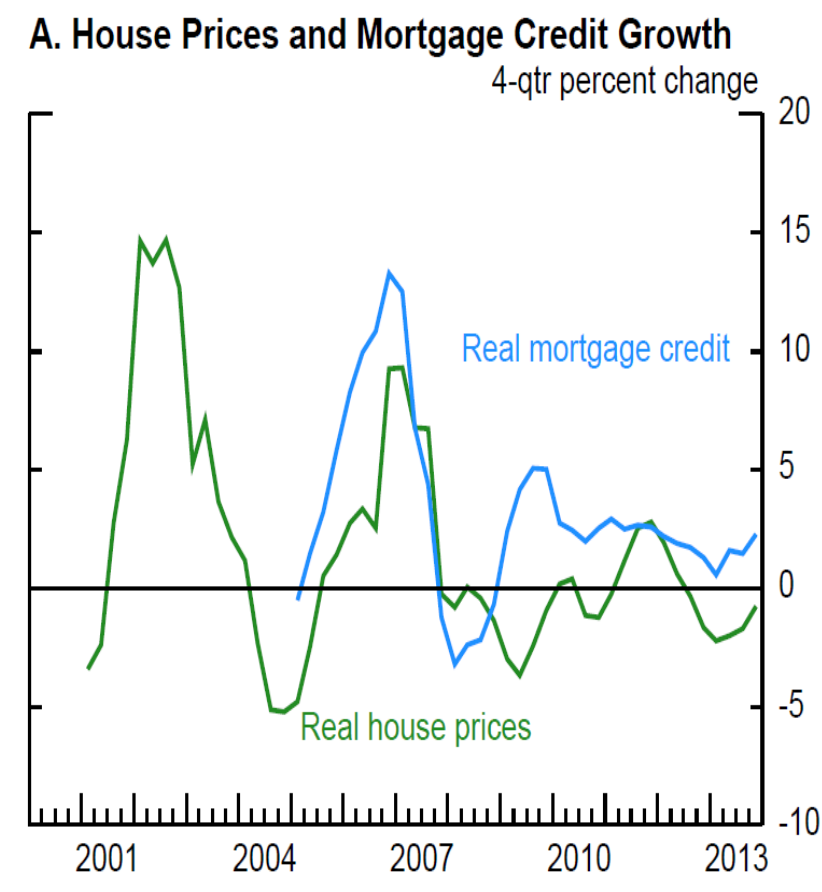

\section{B. New and Cumulative MAPPs}

No. of new measures No. of measures in place

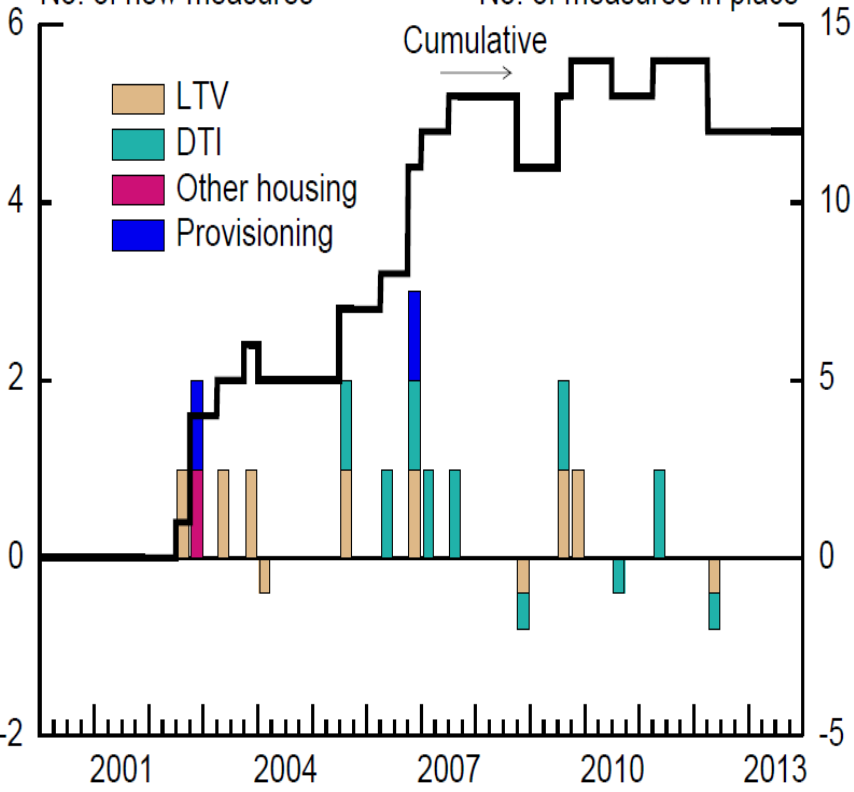

2005, growth in mortgage credit and house prices picked up once more and the government introduced a cap on DTI ratios for the first time in August 2005. The ratio was set at 40 percent for housing loans by banks in speculative zones if the borrower were single or the borrower's spouse had debt. In November 2006, this cap was extended to cover nonspeculative zones in Seoul as well. Later, in August 2007, non-bank financial institutions were subject to DTI caps of between 40 percent and 70 percent. Panel B of figure 6 illustrates how LTV, DTI, and provisioning requirements were subsequently tightened and loosened in response to movements in credit growth and asset prices.

Given the variety and intensity of the measures Korea employed, particularly the housing measures, we engage in an event study analysis of macroprudential tightening events to evaluate the effectiveness of such measures. For both real house prices and real mortgage credit growth, we identify each macroprudential tightening and study a four-quarter window before and after the event. In both cases, we find that macroprudential tools were effective in reducing house price inflation and credit growth (figure 7).

For house prices, we find that house price inflation falls in the four quarters after a tightening. The reduction is dramatic: Average house price inflation in the quarters with MAPP tightenings was 7 percent, while growth in the following quarter fell to just 1 percent. The event study suggests that in subsequent quarters, house prices actually began to contract 
Figure 7: Event Study: House Prices and Housing Credit in Korea

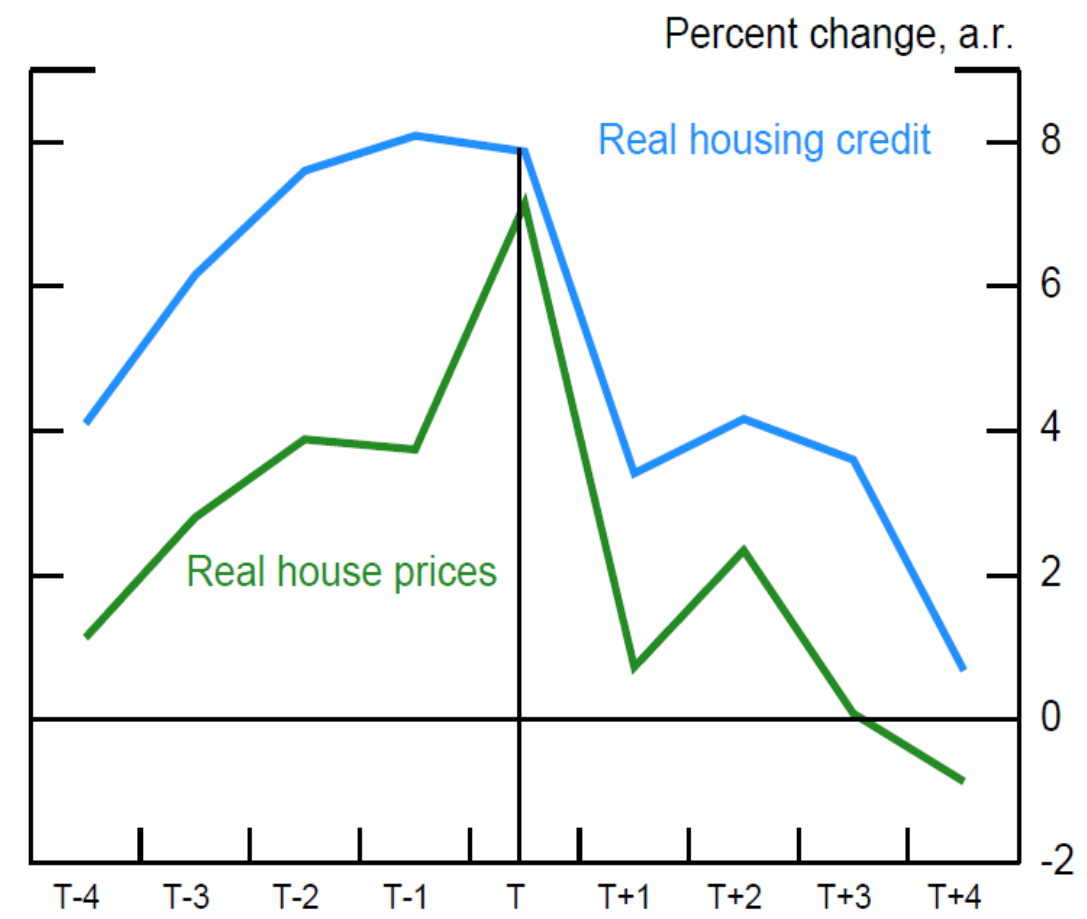

Note: For all macroprudential tightenings in Korea from 2000 to 2013, we study real housing credit growth and real house price inflation for four quarters before and after the event. The blue line displays the average housing credit growth before and after macroprudential tightening measures. The green line shows the average house price inflation around the tightening events. For housing credit, the data begins in 2005 , so some early events are lost.

following MAPP tightenings. Because the Korean authorities were particularly concerned with mortgage credit booms, we conduct the same analysis for mortgage credit; however, the data begin in late 2005, so we lose some events at the beginning of the period. Still, mortgage credit growth also appears to have been contained by the use of housing measures and was likely the driver behind the fall in house prices. In the sections that follow, we undertake a more rigorous examination of the effectiveness of macroprudential policies that exploits our large panel dataset, building off of the encouraging results of the case study for Korea.

\section{Empirical Analysis}

This section lays out the empirical model used in the analysis and presents estimates of the macroprudential policies' effects on total bank credit, housing credit, and house prices. The specification we used in our analysis extends the empirical specification in Kuttner and Shim (2013) along two dimensions: First, a global risk aversion variable proxied by the VIX index is included in the regression. Real and financial conditions in small open economies 
have been shown to be highly correlated with global risk conditions that are exogenous to these countries (see, for example, Akinci (2013)). Inclusion of this variable controls for global cycles in financial conditions in order to disentangle the effect of macroprudential policies on domestic credit conditions. Second, we chose one lag of the change in the monetary policy rate rather than two lags of the level because using the first and second lags together causes each lag to enter with the same coefficient but opposite sign. Including just one lag of the change allows us to better estimate the effect of the other coefficients.

This section also investigates the effects of other policy tools - such as reserve requirements and capital flow management tools - on these variables. We estimate a dynamic panel data regression model with country fixed effects using the Generalized Method of Moments (GMM) method developed by Arellano and Bond (1991). ${ }^{13}$

\subsection{The Empirical Model}

The empirical reduced-form regression model used in the analysis is as follows:

$$
C_{i, t}=\eta_{i}+\rho C_{i, t-1}+\beta V I X_{t}+\sum_{k=1}^{p} \theta_{k} X_{i, t-k}+\delta M A P P_{i, t-1}+\epsilon_{i, t}
$$

where $i$ denotes countries, $t$ indicates time period, and $\eta_{i}$ is a country fixed effect. The dependent variable, $C_{i, t}$, denotes the quarterly (annualized) growth rate of real domestic bank credit. The variable denoted by $M A P P_{i, t}$ is the macroprudential policy index or the housing or nonhousing subcomponents. As mentioned earlier, we chose to use cumulative measures in the panel data analysis because macroprudential measures can affect credit and house price growth not just in the quarter of implementation but in subsequent quarters as well. Some of these policies may be delayed in their effect: Though we record the date the measure was put in place, it could be the case that these measures do not bind until years later. For these reasons, we choose to use the country's overall macroprudential stance as our variable of interest. To address the possible endogeneity of macroprudential measures with respect to financial conditions, we lag the MAPP index by one quarter and also include a vector of control variables, $X_{i, t}$, that includes two lags of quarterly (annualized) real GDP growth and one lag of the change in the nominal monetary policy rate. A global risk aversion variable proxied by the VIX index is also included in the regression. An analogous specification is

\footnotetext{
${ }^{13}$ The estimation results using the Least Square Dummy Variable method, which are qualitatively very similar, are available upon request.
} 
used for the real housing credit and real house prices regressions. ${ }^{14}$

We estimate model (1) by pooling quarterly data from 57 foreign economies (23 advanced and 34 emerging market economies) using the GMM method. The sample begins in 2000:Q1 and ends in 2013:Q4. One concern is that high-risk countries that experienced rapid growth of house prices and credit are most likely to implement macroprudential policies, leading to an endogeneity bias that would increase the correlation between macroprudential policy use and high growth and would bias the coefficient estimates. Therefore if we find some statistical significance of the MAPP indexes to constrain growth of the dependent variables, these should really be considered lower bounds for the true coefficients given the endogeneity of macroprudential policy and high growth in the dependent variables. The GMM technique might also mitigate this type of endogeneity concern. ${ }^{15}$

\subsection{Estimation Results with MAPP Index}

Table 4 reports the regression results for total domestic bank credit growth. The baseline results without our macroprudential indexes (column 1) show all control variables entering significantly with the expected sign. The VIX index, which spikes during episodes of financial stress, is negatively correlated with lower real credit growth. ${ }^{16}$ High GDP growth in the previous two quarters is associated with higher credit growth, while policy rate increases are expected to lower the rate of credit growth.

The next three columns in table 4 show the effect of macroprudential measures on real credit growth. The coefficients on the control variables do not change much when the MAPP indexes are added. Column 2 displays the results for the overall MAPP index, which includes both housing and nonhousing measures. An additional macroprudential measure put in place, measured by an increase in the MAPP index, is associated with a 0.7 percentage point decline in credit growth in a given quarter. The magnitude of the effect is roughly three times that of a 1 percentage point decrease in quarterly GDP growth in the previous quarter. As can be seen from columns 3 and 4, both housing and nonhousing measures have played an important role in containing fast growth in bank credit, with nonhousing measures appearing to have a greater effect than housing-related policies.

\footnotetext{
${ }^{14}$ In the analysis, all nominal variables are deflated by the country's GDP deflator to calculate real variables.

${ }^{15}$ It is also possible that macroprudential policies were implemented at the end of financial boom cycles and credit growth would have naturally declined absent macroprudential policies, but including the VIX in our model helps account for this problem since domestic financial conditions in small open economies are highly correlated with global financial conditions.

${ }^{16}$ We ran the same regression replacing VIX with country-specific banking crisis dummies derived from Valencia and Laeven (2012) and a dummy variable for Eurozone countries during the Eurozone crisis and found similar results.
} 
To test whether housing measures are more effective at curbing credit growth for housing, we run the same set of regressions for the growth of housing credit as the dependent variable. These results are shown in table 5. The baseline and overall MAPP results for housing credit are much the same as for total bank credit (columns 1 and 2), though GDP growth has a smaller predicted effect on housing credit growth, and policy rate increases are not associated with reductions in housing credit growth. From the results in columns 3 and 4, however, it is clear that housing-related measures drive the significance of the overall macroprudential policy index, while nonhousing measures appear to have no significant effect on housing credit growth.

Finally, we investigate whether measures targeted at housing credit can also affect house prices, which can themselves be a source of financial vulnerability. Indeed, in line with our expectation, it seems that housing-related macroprudential measures can significantly lower house price inflation while nonhousing measures do not (table 6). The baseline results are fairly similar as those for bank credit. In the next section, we use these panel estimates for bank credit, housing credit, and house prices to investigate how economically important the macroprudential policy measures were in the countries that used them.

\subsubsection{Counterfactuals}

Are the restraining effects of tighter macroprudential policies economically important? To examine this question, figure 8 shows actual average quarterly credit growth (the first gray bar) for countries that used at least one macroprudential tool from 2011 to 2013. The actual credit growth that occurred in the presence of macroprudential policy is compared with credit growth implied by the model under the counterfactual that no macroprudential measures were in place (the first blue bar). The measures appear to have made a difference: Although average bank credit growth in these countries was still robust even with macroprudential measures in place, it would have been about 25 percent higher in the absence of these measures.

Figure 8 also shows the analogous results for housing credit and house prices. ${ }^{17}$ Consistent with the results of the event study for Korea discussed earlier, our model predicts that house price inflation in countries that enacted at least one housing measure would have been, on average, nearly double its actual level if macroprudential measures had not been used. Housing credit growth would have been more than on and a half times more. Clearly, the macroprudential measures have had a nontrivial effect on credit growth and house price inflation over the past three years.

\footnotetext{
${ }^{17}$ For housing credit and house prices, the figure shows the growth rate of the respective variables for the countries which used at least one housing-related macroprudential measure
} 
Figure 8: Counterfactuals Illustrating Economic Importance of MAPP Measures, 2011-2013

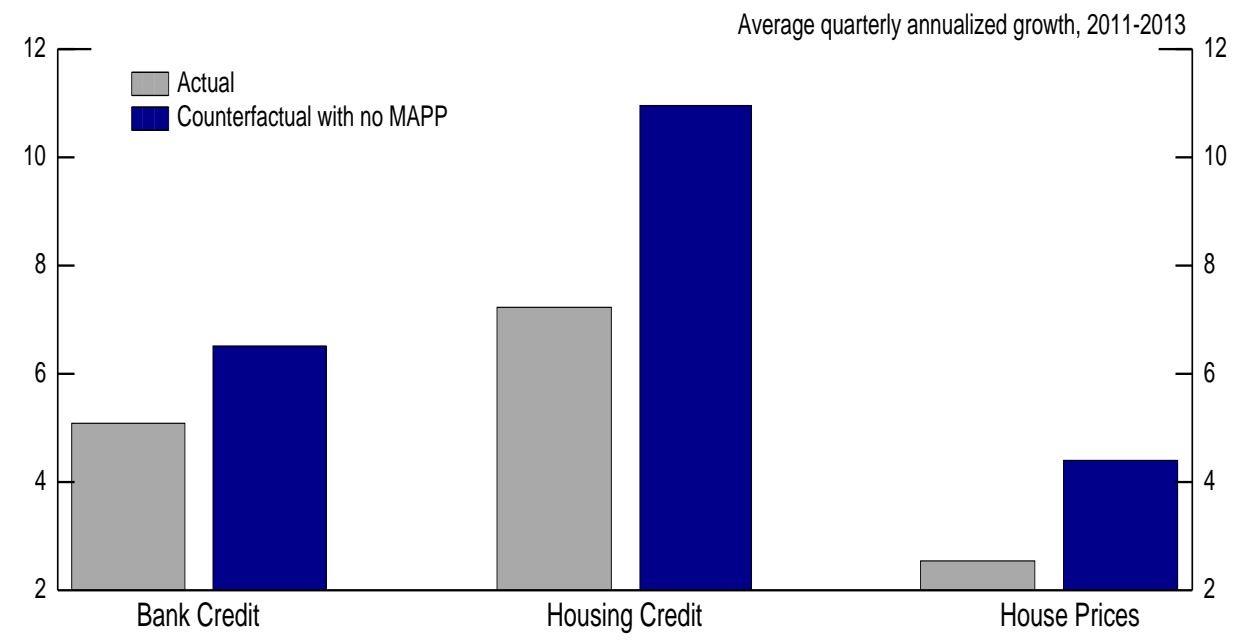

Note: The gray bars show actual average bank and housing credit growth and house price inflation across all countries in our sample that had at least one macroprudential policy (MAPP) in place from 2011 to 2013 (or at least one housing-related MAPP measure for housing credit and house price estimates). The blue bars show, for each dependent variable, our re-estimated average growth, under the counterfactual assumption that no (housing-related) macroprudential policies were in place.

\subsection{Estimation Results with Individual MAPP Measures}

It is of considerable interest to policymakers which instruments are most effective at reducing credit and asset price growth. However, we must proceed with caution when interpreting the results of the regressions with individual measures given that the number of these measures is small, particularly for DTI caps and dynamic provisioning. It may be premature to say that measures not shown to be statistically significant are not effective. With these caveats in mind, this section presents the results of the dynamic panel estimation for the five most common individual macroprudential tools on each of the dependent variables.

For bank credit, three of the five measures are statistically significant, as shown in table 7, and all five enter with the correct (negative) sign. The strongest is capital requirements: Our model predicts that one additional capital requirement reduces credit growth in the following quarter by 1.7 percentage points, though we again note the relatively small number of capital requirement measures in the sample. Housing measures, including LTV caps and other housing measures (mostly made up of risk weights on mortgage loans), are also significant. This result is in line with the findings in table 4 for the overall indexes, which showed both housing and nonhousing measures have a significant effect on credit. It seems that capital requirements - both sectoral requirements on housing loans and general capital requirements - are quite effective in reducing bank credit growth, and that LTV measures targeted at borrowers can also be effective. 
Across all five estimations shown in table 7, the control variables enter significantly with the correct sign. One notable result is the fact that in the regressions where the individual measures are significant, the predicted effect of the policy rate declines slightly and loses some significance. This could be because of correlation between policy rate and the level of macroprudential policies (see table 2), as these two types of instruments are sometimes used in conjunction to address financial stability concerns. ${ }^{18}$

Turning to housing credit, we expect to find that LTV and DTI caps as well as other housing measures reduce housing credit growth, and we do find the borrower-targeted policies (LTV and DTI) are associated with lower housing credit growth (see table 8). The estimated effect of these measures on housing credit is much larger than for total credit, with LTV caps reducing credit growth by 2.9 percentage points and DTI caps by 4.3 percentage points. Because housing credit growth is much larger, on average, than total credit growth, and because these measures target mortgage borrowers specifically, these results make sense. The individual nonhousing measures, with the exception of capital requirements, do not appear to significantly affect housing credit. It appears that nonhousing-related capital requirements are positively correlated with housing credit growth, perhaps because banks increase lending for housing when other types of lending are restricted.

Finally, we consider the effect of each individual measure on house prices with the same expectation that the measures targeted at the housing sector will be more effective. This is indeed the case, as shown in table 9. DTI caps have the greatest predicted effect, reducing quarterly house price growth by nearly 2.3 percentage points, followed by LTV caps (1.5 percentage points) and other housing measures (1 percentage point). We do not find any significant relationship between nonhousing measures and house prices.

\subsection{The Role of Reserve Requirements as a Macroprudential Tool}

Given that we also have data on domestic currency reserve requirements, which are sometimes used as prudential instruments, derived from Cordella et al. (2014), we are also able to study the effects of these measures on our three dependent variables in tables 7,8 , and 9 . In general, reserve requirements do not have a significant effect on credit and house prices when control variables like GDP, global risk, and the policy rate are included in the regressions.

\footnotetext{
${ }^{18}$ We investigated whether the macroprudential policies have been more effective when they used in tandem with other policy tools such as the monetary policy rate. To this aim, we extended the empirical model to include an interaction term between the monetary policy rate and macroprudential policy index. The interaction term is insignificant in the sample of countries we used in our analysis. This result might reflect the fact that our sample consists of heterogeneous set of countries some of which used these two instruments in a way that they complemented each other to achieve the final objective while in other countries these two instruments were substitutes. Section 2.4, in particular figure 5, discusses this issue in a greater detail.
} 
Tighter reserve requirements on domestic currency deposits are weakly positively correlated with bank credit in our sample, a result that is is primarily driven by the effect on the euro area of the actions taken by the European Central Bank, which may or may not be countercyclical for individual countries. There appears to be no significant relationship between credit and reserve requirements once the euro area is excluded from the sample. ${ }^{19}$

\subsection{Capital Controls and Credit Growth in Emerging Countries}

Several countries, especially emerging economies, have employed measures aimed at managing fluctuations in cross-border capital flows and risks associated with these inflows. Surges in capital inflows can cause overheating in credit markets and other financial imbalances, such as excessive borrowing in foreign currencies, by increasing the supply of funds and lowering yields and, in a managed exchange rate regime, by triggering foreign exchange market interventions that expand the money supply if not sterilized. Sudden stops or reversals of inflows can trigger financial crises. Policies to dampen the swings in capital flows, including various types of capital controls, may thus enhance financial stability. Examples include taxes on inflows or special reserve requirements on external deposits. In this respect, the purpose of this section is to investigate the role that capital control policies might play for financial stability purposes. In this section, we check how capital controls, controls on banking inflows, and controls on portfolio inflows affect credit growth.

Table 10, column 1, shows the baseline results for total bank credit growth for the subsample of emerging markets for which there is capital control data. For these 19 countries, the control variables enter with the expected sign and are significant (except for the change in the policy rate.) As with the full panel, the MAPP index is predicted to reduce credit growth. It appears that for these 19 countries, from 2002 to 2012, general capital controls (made up of restrictions on banking inflows, foreign direct investment, and restrictions on portfolio inflows) do not significantly reduce domestic bank credit growth. Portfolio inflow restrictions (including restrictions on bond and equity inflows) do not have any significant effect on credit either. Tighter banking inflow restrictions, on the other hand, are correlated with lower bank credit growth, but the relationship is not significant. When the four Central and Eastern European (CEE) countries in the sample are excluded, however, it is clear that banking inflow restrictions play an important role in the other emerging market countries.

\footnotetext{
${ }^{19}$ We also checked whether there was any interaction between the effectiveness of reserve requirements and macroprudential policy and found no significant relationship.
} 


\subsection{First Look at Spillovers}

One major concern in considering the effectiveness of macroprudential policy is the potential for spillovers or leakage in which macroprudential policies in one country or sector create unintended effects on other countries or sectors. So far we have considered credit from domestic banks to the private sector, but it may be the case that other lenders (non-residents or domestic non-bank lenders) fill in to supply credit when domestic banks are constrained by macroprudential regulations. To investigate such leakage, we check the effect of macroprudential regulations on total credit instead of bank credit. This data from the BIS covers 37 countries $^{20}$ and so we first report the baseline regression results for bank credit for these 37 countries in table 11. As with the sample as a whole, the MAPP index is significant and negative, as is the nonhousing MAPP index. However, from the results reported in table 12, the MAPP indexes have no significant negative effect on total credit, which includes credit from non-residents, corporations, the central bank, households, and the general government, to the non-financial private sector. This suggests that there may be some shift in the supply of credit from banks to other institutions when macroprudential policies are implemented.

\section{Robustness Analysis}

The results in the previous sections lend support to the view that macroprudential policies are effective in curbing bank credit growth and house price inflation. In this section, we analyze whether our results are robust to alternative ways of constructing the MAPP index and in sub-groups of countries. ${ }^{21}$

\subsection{Alternative Ways of Constructing the MAPP Index}

When cumulating the individual measures into the MAPP index used in the regressions, we assign each individual measure a weight of one. It is possible that certain measures should be assigned a greater weight because they have a larger effect on credit growth or house prices than other measures. This is especially true because we use an indicator variable for the individual measures rather than trying to capture the intensity of each action. For example, it is easy to imagine that introducing a general capital buffer reduces credit growth more than a change in the regulatory risk weights on housing loans, but the indicator variable

\footnotetext{
${ }^{20}$ These 37 countries are Argentina, Australia, Austria, Belgium, Brazil, Canada, China, Czech Republic, Denmark, Finland, France, Germany, Greece, Hong Kong, Hungary, India, Indonesia, Ireland, Italy, Japan, Korea, Luxembourg, Malaysia, Mexico, Netherlands, Norway, Poland, Portugal, Russia, Singapore, South Africa, Spain, Sweden, Switzerland, Thailand, Turkey, and United Kingdom.

${ }^{21}$ Regression results and statistical tests for the robustness checks are available upon request.
} 
does not capture this difference. In this section, we check whether our aggregation of the individual MAPP measures is appropriate. Recall that the MAPP index is the sum of each of the individual macroprudential measures, weighted equally:

$$
M A P P_{i, t}=L T V_{i, t}+D T I_{i, t}+\text { Oth.Hous }{ }_{i, t}+C C R_{i, t}+\text { Prov }_{i, t}+\text { Cred.Lim } \text { L }_{i, t}+\text { Cons.Cr. Lim }_{i, t}
$$

Is this weighting appropriate for each country? To check, we run our regressions for credit, housing credit, and house prices again and include $n-1$ individual measures in addition to the MAPP index to see whether any individual measure should have a weight different from 1. A Wald exclusion test (F-test for joint significance) checks whether these additional individual measures should be included. For the panel, the exclusion tests generally suggest that the equal weights across measures are appropriate for each of the dependent variables (the hypothesis that all coefficients on the individual measures are zero cannot be rejected) and thus we do not need to include the individual measures separately or re-weight the index. One exception is for the aggregation of the housing subcomponent with regard to housing credit. In this case we find that LTV and DTI indexes have a much larger effect on housing credit compared with the other housing measures index. We also run the regressions for each country and find only a few cases where the weights for individual measures are statistically different from one.

\subsection{Sub-group Analysis}

Do our results hold up for both advanced and emerging markets? Or is one group of countries driving the results for the sample as a whole? In this section, we investigate how the effects of macroprudential policies vary in advanced economies versus emerging markets.

In table 13 we show the regression results for bank credit with the sample split into advanced and emerging economies. The control variables do not change much for the subsamples, though it appears that global risk plays a smaller role in determining credit growth in emerging economies. The overall MAPP index is negative and significant for both cases, suggesting that macroprudential policies matter for credit growth in both emerging and advanced economies. An interesting result is that housing measures drive the results for advanced economies while nonhousing policies matter more in emerging markets, consistent with what we observe in figure 4 that emerging markets have used broad, non-housing policies, while advanced economies have generally used policies that specifically apply to the housing sector. The housing-related policies used in emerging markets do not appear to be associated with lower bank credit growth. 
For housing credit, as with total credit, we find that macroprudential policy tightenings matter in both advanced and emerging markets (table 14). In both groups, it is housingrelated macroprudential policies that drive the results for the overall index. It seems that monetary policy tightenings are weakly associated with higher housing credit growth in advanced economies, which explains why in the sample as a whole (table 5) we did not find the expected relationship between policy rate increases and housing credit growth. The results for house price inflation are very similar to those for housing credit (table 15). Housing-related policies matter for house price inflation while nonhousing measures do not.

\section{Conclusion}

In this paper, we have used a dynamic panel data model to assess the effectiveness of macroprudential policies. To do so, we develop a novel set of indexes for seven macroprudential tools (LTV, DTI, other housing measures, countercyclical capital requirements, dynamic provisioning, consumer loan limits, and credit growth ceilings) as well as an aggregate index to measure the overall macroprudential policy stance of 57 countries. We have used national sources and IMF survey results to update and improve existing databases of macroprudential policies to cover three years more than most of the empirical literature, a period in which macroprudential policies were heavily used.

This study analyzes how a country's general macroprudential policy stance, as well as its stance with regard to one particular sector, housing, affects credit growth and house prices. We find that bank credit growth is restrained by both housing and nonhousing measures. Analysis on the individual level suggests capital requirements are effective, along with LTV caps, risk weights on mortgages, and other housing measures. Our results predict that only housing-related macroprudential policies constrain housing credit growth and house price inflation, particularly LTV and DTI caps. Counterfactual simulations from the model assuming countries had not used any macroprudential measures predict that average bank credit growth, housing credit growth, and house price inflation would all have been significantly higher between 2011 to 2013 in the absence of macroprudential policy.

Future work on the efficacy of macroprudential policy should address several concerns. Although we find little mutual reinforcement of macroprudential policies and capital controls with regard to bank credit growth, it is likely that the two policy options both affect capital flows, and this relationship should be investigated further. More research should also be done to understand the domestic spillovers from macroprudential policy in some sectors, especially the effect of housing-related policies on other sectors. 


\section{References}

Acharya, V. V., Oct. 2013. Adapting macroprudential regulation for emerging markets. In: Canuto, O., Ghosh, S. (Eds.), Dealing with the Challenges of Macro Financial Linkages in Emerging Markets. Ch. 2. 1

Ahmed, S., Zlate, A., 2014. Capital flows to emerging market economies: A brave new world? Journal of International Money and Finance (0),- .

URL http://www.sciencedirect.com/science/article/pii/S0261560614000928 2.4, $3,2.4,11$

Aiyar, S., Calomiris, C. W., Wieladek, T., 2014. Does macro-prudential regulation leak? evidence from a uk policy experiment. Journal of Money, Credit and Banking 46 (s1), 181214.

URL http://dx.doi.org/10.1111/jmcb.12086 1

Akinci, O., 2013. Global financial conditions, country spreads and macroeconomic fluctuations in emerging countries. Journal of International Economics. 4

Arellano, M., Bond, S., April 1991. Some tests of specification for panel data: Monte carlo evidence and an application to employment equations. Review of Economic Studies 58 (2), 277-97.

URL http://ideas.repec.org/a/bla/restud/v58y1991i2p277-97.html 4

Bruno, V., Shim, I., Shin, H. S., Oct. 2014. Comparative Assessment of Macroprudential Policies. Tech. rep., Bank for International Settlements. 1

Cerutti, E., Claessens, S., Laeven, L., 2015a. The Use and Effectiveness of Macroprudential Policies: New Evidence. IMF Working Papers 15/61, International Monetary Fund. 1, 2.1

Cerutti, E., Correa, R., Fiorentino, E., Segalla, E., 2015b. Changes in prudential policy instruments a new cross country database. 2.1

Claessens, S., Ghosh, S. R., Mihet, R., 2014. Macro-Prudential Policies to Mitigate Financial System Vulnerabilities. IMF Working Papers 14/155, International Monetary Fund.

URL http://www.imf .org/external/pubs/ft/wp/2014/wp14155.pdf 1

Cordella, T., Federico, P., Vegh, C., Vuletin, G., Feb. 2014. Reserve requirements in the brave new macroprudential world. Policy Research Working Paper Series 6793, The World Bank. URL http://ideas.repec.org/p/wbk/wbrwps/6793.html 2.4, 4.4 
Craig, R. S., Hua, C., 2011. Determinants of Property Prices in Hong Kong SAR: Implications for Policy. IMF Working Papers 11/277, International Monetary Fund.

URL https://www.imf .org/external/pubs/ft/wp/2011/wp11277.pdf 1

DellAriccia, G., Igan, D., Laeven, L., Tong, H., 2012. Policies for Macrofinancial Stability: How to Deal with Credit Booms. IMF Staff Discussion Note 12/06, International Monetary Fund.

URL http://www.imf .org/external/pubs/ft/sdn/2012/sdn1206.pdf 1

Gourinchas, P.-O., Obstfeld, M., January 2012. Stories of the twentieth century for the twentyfirst. American Economic Journal: Macroeconomics 4 (1), 226-65.

URL http://ideas.repec.org/a/aea/aejmac/v4y2012i1p226-65.html 2

IMF, Dec. 2012. The Interaction of Monetary and Macroprudential Policies-Background Paper. Tech. rep., International Monetary Fund.

URL https://www.imf .org/external/np/pp/eng/2013/012713.pdf 1

IMF, 2014. United Kingdom: Selected Issues. IMF Country Report 14/234, International Monetary Fund.

URL http://www.imf .org/external/pubs/ft/scr/2014/cr14234.pdf 1

Kuttner, K. N., Shim, I., Dec. 2013. Can Non-Interest Rate Policies Stabilize Housing Markets? Evidence from a Panel of 57 Economies. NBER Working Papers 19723, National Bureau of Economic Research, Inc.

URL http://ideas.repec.org/p/nbr/nberwo/19723.html 1, 4, Appendix C

Lim, C. H., Costa, A., Columba, F., Kongsamut, P., Otani, A., Saiyid, M., Wezel, T., Wu, X., 2011. Macroprudential Policy: What Instruments and How to Use Them? Lessons from Country Experiences. IMF Working Papers 11/238, International Monetary Fund.

URL http://ssrn.com/abstract=2169749 1, 2.1

Mendoza, E. G., Terrones, M. E., Sep. 2012. An anatomy of credit booms and their demise. NBER Working Papers 18379, National Bureau of Economic Research, Inc.

URL http://ideas.repec.org/p/nbr/nberwo/18379.html 2

Schularick, M., Taylor, A. M., 2012. Credit booms gone bust: Monetary policy, leverage cycles, and financial crises, 1870-2008. American Economic Review 102 (2), 1029-61.

URL http://www . aeaweb.org/articles.php?doi=10.1257/aer.102.2.10292 
Shim, I., Bogdanova, B., Shek, J., Subeltye, A., September 2013. Database for policy actions on housing markets. BIS Quarterly Review.

URL http://ideas.repec.org/a/bis/bisqtr/1309i.html 1, 2.1

Valencia, F., Laeven, L., Jun. 2012. Systemic Banking Crises Database: An Update. IMF Working Papers 12/163, International Monetary Fund.

URL http://ideas.repec.org/p/imf/imfwpa/12-163.html 16

Vandenbussche, J., Vogel, U., Detragiache, E., 2012. Macroprudential Policies and Housing Prices-A New Database and Empirical Evidence for Central, Eastern, and Southeastern Europe. IMF Working Papers 12/303, International Monetary Fund.

URL http://ssrn. com/abstract=1956385 1

Zhang, L., Zoli, E., 2014. Leaning Against the Wind: Macroprudential Policy in Asia. IMF Working Papers 14/22, International Monetary Fund.

URL https://www.imf .org/external/pubs/ft/wp/2014/wp1422.pdf 1 
Table 4: Panel Estimation Results: Bank Credit, 2000:Q1 to 2013:Q4

\begin{tabular}{|c|c|c|c|c|}
\hline & Baseline & With MAPP & With MAPPH & With MAPPNH \\
\hline \multirow[t]{2}{*}{ L.Real Cred. Growth } & $0.325^{* * *}$ & $0.311^{* * *}$ & $0.315^{* * *}$ & $0.316^{* * *}$ \\
\hline & $(0.04)$ & $(0.04)$ & $(0.04)$ & $(0.04)$ \\
\hline \multirow[t]{2}{*}{ VIX (log) } & $-1.877^{* *}$ & $-2.059^{* *}$ & $-2.144^{* *}$ & $-1.797^{*}$ \\
\hline & $(0.91)$ & $(0.95)$ & $(0.96)$ & $(0.93)$ \\
\hline \multirow[t]{2}{*}{ GDP growth, 1st lag } & $0.262^{* * *}$ & $0.241^{* * * *}$ & $0.245^{* * *}$ & $0.254^{* * *}$ \\
\hline & $(0.06)$ & $(0.06)$ & $(0.06)$ & $(0.06)$ \\
\hline \multirow[t]{2}{*}{ GDP growth, 2nd lag } & $0.305^{* * *}$ & $0.287^{* * *}$ & $0.290^{* * *}$ & $0.298^{* * *}$ \\
\hline & $(0.05)$ & $(0.04)$ & $(0.04)$ & $(0.04)$ \\
\hline \multirow[t]{2}{*}{ Chg. in pol. rate, 1st lag } & $-1.162^{*}$ & -0.995 & -1.066 & -1.033 \\
\hline & $(0.68)$ & $(0.68)$ & $(0.69)$ & $(0.67)$ \\
\hline \multirow[t]{2}{*}{ MAPP, 1st lag } & & $-0.728^{* * *}$ & & \\
\hline & & $(0.27)$ & & \\
\hline \multicolumn{2}{|l|}{ MAPPH, 1st lag } & & $\begin{array}{r}-0.834^{* *} \\
(0.38)\end{array}$ & \\
\hline MAPPNH, 1st lag & & & & $\begin{array}{r}-1.139^{* *} \\
(0.49)\end{array}$ \\
\hline Observations & 2728 & 2728 & 2728 & 2728 \\
\hline No. of countries & 55 & 55 & 55 & 55 \\
\hline
\end{tabular}

Note: Robust standard errors clustered by country are in parentheses. ${ }^{*} \mathrm{p}<0.1,{ }^{* *} \mathrm{p}<0.05, * * * \mathrm{p}<0.01$. MAPP is the overall cumulative macroprudential policy index that sums housing-related and nonhousing measures. MAPPH is the cumulative housing-related macroprudential policy index. MAPPNH is the cumulative nonhousing-related macroprudential policy index. 
Table 5: Panel Estimation Results: Housing Credit, 2000:Q1 to 2013:Q4

\begin{tabular}{lrrrr} 
& Baseline & With MAPP & With MAPPH & With MAPPNH \\
\hline L.Real Housing Cred. Growth & $0.517^{* * *}$ & $0.506^{* * *}$ & $0.500^{* * *}$ & $0.517^{* * *}$ \\
& $(0.07)$ & $(0.07)$ & $(0.07)$ & $(0.07)$ \\
VIX $(\log )$ & $-1.993^{*}$ & $-2.350^{* *}$ & $-2.457^{* *}$ & $-1.977^{*}$ \\
& $(1.02)$ & $(1.03)$ & $(1.01)$ & $(1.04)$ \\
GDP growth, 1st lag & $0.164^{* * *}$ & $0.146^{* * *}$ & $0.141^{* * *}$ & $0.166^{* * *}$ \\
& $(0.06)$ & $(0.06)$ & $(0.05)$ & $(0.06)$ \\
GDP growth, 2nd lag & $0.129^{* *}$ & $0.117^{* *}$ & $0.113^{*}$ & $0.130^{* *}$ \\
& $(0.06)$ & $(0.06)$ & $(0.06)$ & $(0.06)$ \\
Change in policy rate, 1st lag & 0.496 & 0.608 & 0.591 & 0.478 \\
& $(0.64)$ & $(0.60)$ & $(0.61)$ & $(0.62)$ \\
\hline MAPP, 1st lag & & $-0.709^{*}$ & & \\
MAPPH, 1st lag & & $(0.37)$ & & \\
& & & $-1.125^{* * *}$ & \\
MAPPNH, 1st lag & & & & \\
& & & & \\
& & & & \\
Observations & 5382 & 2382 & 2382 & $(1.08)$ \\
No. of countries & 53 & 53 & 53 \\
\hline
\end{tabular}

Note: Robust standard errors clustered by country are in parentheses. ${ }^{*} \mathrm{p}<0.1,{ }^{* *} \mathrm{p}<0.05,{ }^{* * *} \mathrm{p}<0.01$. MAPP is the overall cumulative macroprudential policy index that sums housing-related and nonhousing measures. MAPPH is the cumulative housing-related macroprudential policy index. MAPPNH is the cumulative nonhousing-related macroprudential policy index. 
Table 6: Panel Estimation Results: House Prices, 2000:Q1 to 2013:Q4

\begin{tabular}{|c|c|c|c|c|}
\hline & Baseline & With MAPP & With MAPPH & With MAPPNH \\
\hline \multirow[t]{2}{*}{ L.Real House Price Growth } & $0.198 * * *$ & $0.193^{* * *}$ & $0.191^{* * *}$ & $0.198^{* * *}$ \\
\hline & $(0.07)$ & $(0.07)$ & $(0.07)$ & $(0.07)$ \\
\hline \multirow[t]{2}{*}{ VIX (log) } & $-4.918^{* * *}$ & $-5.174 * * *$ & $-5.249 * * *$ & $-4.927^{* * *}$ \\
\hline & $(1.21)$ & $(1.24)$ & $(1.24)$ & $(1.21)$ \\
\hline \multirow[t]{2}{*}{ GDP growth, 1st lag } & $0.254^{* * *}$ & $0.239^{* * *}$ & $0.239^{* * *}$ & $0.252^{* * *}$ \\
\hline & $(0.08)$ & $(0.08)$ & $(0.08)$ & $(0.08)$ \\
\hline \multirow[t]{2}{*}{ GDP growth, 2nd lag } & $0.212^{* * *}$ & $0.198^{* * *}$ & $0.199 * * *$ & $0.209^{* * *}$ \\
\hline & $(0.06)$ & $(0.06)$ & $(0.06)$ & $(0.06)$ \\
\hline \multirow[t]{2}{*}{ Change in policy rate, 1 st lag } & $-1.374^{* *}$ & $-1.241^{* *}$ & $-1.241^{* *}$ & $-1.357^{* *}$ \\
\hline & $(0.61)$ & $(0.61)$ & $(0.61)$ & $(0.60)$ \\
\hline \multirow[t]{2}{*}{ MAPP, 1st lag } & & $-0.521^{* * *}$ & & \\
\hline & & $(0.18)$ & & \\
\hline \multirow[t]{2}{*}{ MAPPH, 1st lag } & & & $-0.706^{* * *}$ & \\
\hline & & & $(0.23)$ & \\
\hline \multirow[t]{2}{*}{ MAPPNH, 1st lag } & & & & -0.277 \\
\hline & & & & $(0.50)$ \\
\hline Observations & 2350 & 2350 & 2350 & 2350 \\
\hline No. of countries & 53 & 53 & 53 & 53 \\
\hline
\end{tabular}

Note: Robust standard errors clustered by country are in parentheses. ${ }^{*} \mathrm{p}<0.1,{ }^{* *} \mathrm{p}<0.05,{ }^{* * *} \mathrm{p}<0.01$. MAPP is the overall cumulative macroprudential policy index that sums housing-related and nonhousing measures. MAPPH is the cumulative housing-related macroprudential policy index. MAPPNH is the cumulative nonhousing-related macroprudential policy index. 
Table 7: Individual Measures: Panel Estimation Results: Bank Credit, 2000:Q1 to 2013:Q4

\begin{tabular}{|c|c|c|c|c|c|c|}
\hline & $(1)$ & $(2)$ & (3) & (4) & (5) & (6) \\
\hline L.Real Cred. Growth & $\begin{array}{r}0.316^{* * *} \\
(0.04)\end{array}$ & $\begin{array}{r}0.318^{* * *} \\
(0.04)\end{array}$ & $\begin{array}{r}0.322^{* * *} \\
(0.04)\end{array}$ & $\begin{array}{r}0.320^{* * *} \\
(0.04)\end{array}$ & $\begin{array}{r}0.319^{* * *} \\
(0.04)\end{array}$ & $\begin{array}{r}0.315^{* * *} \\
(0.04)\end{array}$ \\
\hline VIX (log) & $\begin{array}{r}-2.078^{* *} \\
(0.95)\end{array}$ & $\begin{array}{r}-1.793^{* *} \\
(0.89)\end{array}$ & $\begin{array}{r}-2.100^{* *} \\
(0.95)\end{array}$ & $\begin{array}{r}-1.868^{* *} \\
(0.91)\end{array}$ & $\begin{array}{r}-1.776^{*} \\
(0.94)\end{array}$ & $\begin{array}{r}-2.047^{* *} \\
(0.94)\end{array}$ \\
\hline GDP growth, 1st lag & $\begin{array}{r}0.249^{* * *} \\
(0.06)\end{array}$ & $\begin{array}{r}0.254^{* * *} \\
(0.06)\end{array}$ & $\begin{array}{r}0.252^{* * *} \\
(0.06)\end{array}$ & $\begin{array}{r}0.252^{* * *} \\
(0.06)\end{array}$ & $\begin{array}{r}0.260^{* * * *} \\
(0.06)\end{array}$ & $\begin{array}{r}0.268^{* * *} \\
(0.06)\end{array}$ \\
\hline GDP growth, 2nd lag & $\begin{array}{r}0.294^{* * *} \\
(0.05)\end{array}$ & $\begin{array}{r}0.299^{* * *} \\
(0.04)\end{array}$ & $\begin{array}{r}0.297 * * * \\
(0.04)\end{array}$ & $\begin{array}{r}0.297^{* * *} \\
(0.05)\end{array}$ & $\begin{array}{r}0.303^{* * *} \\
(0.05)\end{array}$ & $\begin{array}{r}0.305^{* * *} \\
(0.04)\end{array}$ \\
\hline Chg. in pol. rate, 1 st lag & $\begin{array}{r}-1.086 \\
(0.69)\end{array}$ & $\begin{array}{r}-1.125 \\
(0.69)\end{array}$ & $\begin{array}{r}-1.112 \\
(0.68)\end{array}$ & $\begin{array}{r}-1.067 \\
(0.66) \\
\end{array}$ & $\begin{array}{r}-1.102 \\
(0.68) \\
\end{array}$ & $\begin{array}{r}-1.325^{* *} \\
(0.65) \\
\end{array}$ \\
\hline LTV, 1st lag & $\begin{array}{r}-1.458^{*} \\
(0.86)\end{array}$ & & & & & \\
\hline DTI, 1st lag & & $\begin{array}{r}-2.543 \\
(1.79)\end{array}$ & & & & \\
\hline Other Housing, 1st lag & & & $\begin{array}{r}-1.027^{* *} \\
(0.52)\end{array}$ & & & \\
\hline CCR, 1st lag & & & & $\begin{array}{r}-1.684^{* *} \\
(0.75)\end{array}$ & & \\
\hline Prov., 1st lag & & & & & $\begin{array}{r}-1.992 \\
(1.25)\end{array}$ & \\
\hline Res. Req., 1st lag & & & & & & $\begin{array}{r}0.417^{*} \\
(0.24) \\
\end{array}$ \\
\hline Observations & 2728 & 2728 & 2728 & 2728 & 2728 & 2698 \\
\hline No. of countries & 55 & 55 & 55 & 55 & 55 & 55 \\
\hline
\end{tabular}

Note: Robust standard errors clustered by country are in parentheses. ${ }^{*} \mathrm{p}<0.1, * * \mathrm{p}<0.05, * * * \mathrm{p}<0.01$. LTV is the cumulative index of loan-to-value caps. DTI is the cumulative index of debt-to-income caps. Other Housing is the cumulative index of housing-related measures other than LTV and DTI caps. CCR is the cumulative capital requirement index. Prov. is the cumulative loan-loss provisioning index. Res. Req. is the cumulative index of domestic currency reserve requirements. 
Table 8: Individual Measures: Panel Estimation Results: Housing Credit, 2000:Q1 to 2013:Q4

\begin{tabular}{|c|c|c|c|c|c|c|}
\hline & $(1)$ & $(2)$ & $(3)$ & $(4)$ & $(5)$ & $(6)$ \\
\hline \multirow[t]{2}{*}{ L.Real Housing Cred. Growth } & $0.495 * * *$ & $0.493^{* * *}$ & $0.515^{* * *}$ & $0.512^{* * *}$ & $0.516^{* * *}$ & $0.517^{* * *}$ \\
\hline & $(0.07)$ & $(0.08)$ & $(0.07)$ & $(0.07)$ & $(0.07)$ & $(0.07)$ \\
\hline \multirow[t]{2}{*}{ VIX (log) } & $-2.551^{* *}$ & $-1.928^{*}$ & $-2.181^{* *}$ & $-1.861^{*}$ & $-1.992^{*}$ & $-2.093^{* *}$ \\
\hline & $(1.06)$ & $(1.01)$ & $(0.99)$ & $(1.07)$ & $(1.03)$ & $(1.01)$ \\
\hline \multirow[t]{2}{*}{ GDP growth, 1st lag } & $0.138^{* *}$ & $0.150^{* *}$ & $0.158 * * *$ & $0.177^{* * *}$ & $0.164^{* * *}$ & $0.162^{* * *}$ \\
\hline & $(0.06)$ & $(0.06)$ & $(0.05)$ & $(0.06)$ & $(0.06)$ & $(0.06)$ \\
\hline \multirow[t]{2}{*}{ GDP growth, 2nd lag } & $0.111^{*}$ & $0.115^{* *}$ & $0.126^{* *}$ & $0.137^{* *}$ & $0.129 * *$ & $0.130 * *$ \\
\hline & $(0.06)$ & $(0.06)$ & $(0.06)$ & $(0.06)$ & $(0.06)$ & $(0.06)$ \\
\hline \multirow[t]{2}{*}{ Chg. in pol. rate, 1 st lag } & 0.622 & 0.566 & 0.514 & 0.467 & 0.431 & 0.354 \\
\hline & $(0.62)$ & $(0.62)$ & $(0.63)$ & $(0.64)$ & $(0.65)$ & $(0.64)$ \\
\hline LTV, 1st lag & $\begin{array}{r}-2.872^{* * *} \\
(1.09)\end{array}$ & & & & & \\
\hline DTI, 1st lag & & $\begin{array}{r}-4.337^{* *} \\
(2.12)\end{array}$ & & & & \\
\hline Other Housing, 1st lag & & & $\begin{array}{r}-0.797 \\
(0.92)\end{array}$ & & & \\
\hline CCR, 1st lag & & & & $\begin{array}{r}2.735^{*} \\
(1.42)\end{array}$ & & \\
\hline Prov., 1st lag & & & & & $\begin{array}{c}2.143 \\
(1.97)\end{array}$ & \\
\hline Res. Req., 1st lag & & & & & & $\begin{array}{r}0.234 \\
(0.63) \\
\end{array}$ \\
\hline Observations & 2382 & 2382 & 2382 & 2382 & 2382 & 2363 \\
\hline No. of countries & 53 & 53 & 53 & 53 & 53 & 53 \\
\hline
\end{tabular}

Note: Robust standard errors clustered by country are in parentheses. ${ }^{*} \mathrm{p}<0.1, * * \mathrm{p}<0.05, * * * \mathrm{p}<0.01$. LTV is the cumulative index of loan-to-value caps. DTI is the cumulative index of debt-to-income caps. Other Housing is the cumulative index of housing-related measures other than LTV and DTI caps. CCR is the cumulative capital requirement index. Prov. is the cumulative loan-loss provisioning index. Res. Req. is the cumulative index of domestic currency reserve requirements. 
Table 9: Individual Measures: Panel Estimation Results: House Prices, 2000:Q1 to 2013:Q4

\begin{tabular}{|c|c|c|c|c|c|c|}
\hline \multirow{3}{*}{ L.Real House Price Growth } & $(1)$ & $(2)$ & (3) & $(4)$ & $(5)$ & (6) \\
\hline & $0.191^{* * *}$ & $0.193^{* * *}$ & $0.195^{* * *}$ & $0.197^{* * *}$ & $0.196^{* * *}$ & $0.197^{* * *}$ \\
\hline & $(0.07)$ & $(0.07)$ & $(0.07)$ & $(0.07)$ & $(0.07)$ & $(0.07)$ \\
\hline \multirow{2}{*}{ VIX $(\log )$} & $-5.283^{* * *}$ & $-4.914^{* * *}$ & $-5.143^{* * *}$ & $-4.934^{* * *}$ & $-4.950^{* * *}$ & $-4.929^{* * *}$ \\
\hline & $(1.25)$ & $(1.22)$ & $(1.24)$ & $(1.21)$ & $(1.21)$ & (1.19) \\
\hline GDP growth, 1st lag & $\begin{array}{r}0.240^{* * *} \\
(0.08)\end{array}$ & $\begin{array}{r}0.247^{* * *} \\
(0.08)\end{array}$ & $\begin{array}{r}0.246^{* * *} \\
(0.08)\end{array}$ & $\begin{array}{r}0.251^{* * *} \\
(0.08)\end{array}$ & $\begin{array}{r}0.256^{* * * *} \\
(0.08)\end{array}$ & $\begin{array}{r}0.256^{* * *} \\
(0.08)\end{array}$ \\
\hline GDP growth, 2nd lag & $\begin{array}{r}0.199^{* * *} \\
(0.06)\end{array}$ & $\begin{array}{r}0.203^{* * *} \\
(0.06)\end{array}$ & $\begin{array}{r}0.205^{* * *} \\
(0.06)\end{array}$ & $\begin{array}{r}0.208^{* * *} \\
(0.06)\end{array}$ & $\begin{array}{r}0.212^{* * * *} \\
(0.06)\end{array}$ & $\begin{array}{r}0.210^{* * *} \\
(0.06)\end{array}$ \\
\hline Chg. in pol. rate, 1 st lag & $\begin{array}{r}-1.241^{* *} \\
(0.61)\end{array}$ & $\begin{array}{r}-1.284^{* *} \\
(0.61)\end{array}$ & $\begin{array}{r}-1.312^{* *} \\
(0.61)\end{array}$ & $\begin{array}{r}-1.361^{* *} \\
(0.60)\end{array}$ & $\begin{array}{r}-1.399^{* *} \\
(0.61)\end{array}$ & $\begin{array}{r}-1.385^{* *} \\
(0.60)\end{array}$ \\
\hline LTV, 1st lag & $\begin{array}{r}-1.519^{* * *} \\
(0.51)\end{array}$ & & & & & \\
\hline DTI, 1st lag & & $\begin{array}{r}-2.302^{*} \\
(1.23)\end{array}$ & & & & \\
\hline Other Housing, 1st lag & & & $\begin{array}{r}-0.986^{* *} \\
(0.42)\end{array}$ & & & \\
\hline CCR, 1st lag & & & & $\begin{array}{c}-0.584 \\
(0.91)\end{array}$ & & \\
\hline Prov., 1st lag & & & & & $\begin{array}{r}1.418 \\
(1.02)\end{array}$ & \\
\hline Res. Req., 1st lag & & & & & & $\begin{array}{r}-0.056 \\
(0.23)\end{array}$ \\
\hline Observations & 2350 & 2350 & 2350 & 2350 & 2350 & 2330 \\
\hline No. of countries & 53 & 53 & 53 & 53 & 53 & 53 \\
\hline
\end{tabular}

Note: Robust standard errors clustered by country are in parentheses. ${ }^{*} \mathrm{p}<0.1,{ }^{* *} \mathrm{p}<0.05, * * * \mathrm{p}<0.01$. LTV is the cumulative index of loan-to-value caps. DTI is the cumulative index of debt-to-income caps. Other Housing is the cumulative index of housing-related measures other than LTV and DTI caps. CCR is the cumulative capital requirement index. Prov. is the cumulative loan-loss provisioning index. Res. Req. is the cumulative index of domestic currency reserve requirements. 
Table 10: Capital Flow Management Panel Estimation Results: Bank Credit, 2002:Q1 to 2012:Q4

\begin{tabular}{|c|c|c|c|c|c|c|}
\hline & (1) & $(2)$ & (3) & $(4)$ & $(5)$ & (5A: Ex. CEE) \\
\hline \multirow[t]{2}{*}{ L.Real Cred. Growth } & $0.237^{* * *}$ & $0.234^{* * *}$ & $0.233^{* * *}$ & $0.234^{* * *}$ & $0.232^{* * *}$ & $0.192^{* * *}$ \\
\hline & $(0.07)$ & $(0.07)$ & $(0.06)$ & $(0.06)$ & $(0.06)$ & $(0.07)$ \\
\hline \multirow[t]{2}{*}{ VIX (log) } & $-2.478^{*}$ & $-2.362^{*}$ & $-2.607^{*}$ & $-2.637^{*}$ & $-2.662^{* *}$ & $-3.480 * *$ \\
\hline & $(1.30)$ & $(1.27)$ & $(1.34)$ & $(1.38)$ & $(1.27)$ & $(1.45)$ \\
\hline \multirow[t]{2}{*}{ GDP growth, 1st lag } & $0.244^{* *}$ & $0.238 * *$ & $0.241^{* *}$ & $0.241^{* *}$ & $0.240^{* *}$ & $0.168^{*}$ \\
\hline & $(0.10)$ & $(0.10)$ & $(0.10)$ & $(0.10)$ & $(0.10)$ & $(0.10)$ \\
\hline \multirow[t]{2}{*}{ GDP growth, 2nd lag } & $0.383^{* * *}$ & $0.383^{* * *}$ & $0.381^{* * *}$ & $0.382^{* * *}$ & $0.379 * * *$ & $0.252^{* * *}$ \\
\hline & $(0.10)$ & $(0.10)$ & $(0.10)$ & $(0.10)$ & $(0.10)$ & $(0.07)$ \\
\hline \multirow[t]{2}{*}{ Chg. in pol. rate, 1st lag } & -0.724 & -0.630 & -0.680 & -0.670 & -0.661 & -0.515 \\
\hline & $(0.95)$ & $(0.90)$ & $(1.04)$ & $(1.04)$ & $(1.03)$ & $(1.19)$ \\
\hline MAPP, 1st lag & & $-0.414^{*}$ & & & & \\
\hline \multirow{2}{*}{ Overall CFM, 1st lag } & & $(0.2 .0)$ & 0.153 & & & \\
\hline & & & $(0.23)$ & & & \\
\hline \multirow[t]{2}{*}{ Port. CFM, 1st lag } & & & & 0.288 & & \\
\hline & & & & $(0.29)$ & & \\
\hline \multirow[t]{2}{*}{ Bank CFM, 1st lag } & & & & & -0.354 & $-0.624^{* *}$ \\
\hline & & & & & $(0.39)$ & $(0.32)$ \\
\hline Observations & 799 & 799 & 774 & 774 & 774 & 618 \\
\hline No. of countries & 19 & 19 & 19 & 19 & 19 & 15 \\
\hline
\end{tabular}

Note: Robust standard errors clustered by country are in parentheses. Sample period is 2002-2012 and includes 19 emerging market economies. ${ }^{*} \mathrm{p}<0.1,{ }^{* *} \mathrm{p}<0.05,{ }^{* * *} \mathrm{p}<0.01$. MAPP is the overall cumulative macroprudential policy index that sums housing-related and nonhousing measures. Overall CFM is the cumulative index of capital flow restrictions on banking inflows, portfolio inflows, and foreign direct investment inflows. Port. CFM is the cumulative portfolio subcomponent of the Overall CFM index. Bank CFM is the cumulative banking subcomponent of the Overall CFM index. 
Table 11: Panel Estimation Results: Bank Credit, 2000:Q1 to 2013:Q4

\begin{tabular}{|c|c|c|c|c|}
\hline & Baseline & With MAPP & With MAPPH & With MAPPNH \\
\hline \multirow[t]{2}{*}{ L.Real Cred. Growth } & $0.321^{* * *}$ & $0.317^{* * *}$ & $0.318^{* * *}$ & $0.319^{* * *}$ \\
\hline & $(0.04)$ & $(0.04)$ & $(0.04)$ & $(0.04)$ \\
\hline \multirow[t]{2}{*}{ VIX $(\log )$} & -0.824 & -0.939 & -0.951 & -0.830 \\
\hline & $(0.88)$ & $(0.88)$ & $(0.88)$ & $(0.87)$ \\
\hline \multirow[t]{2}{*}{ GDP growth, 1st lag } & $0.238^{* * *}$ & $0.228^{* * *}$ & $0.229^{* * * *}$ & $0.235^{* * *}$ \\
\hline & $(0.05)$ & $(0.05)$ & $(0.05)$ & $(0.05)$ \\
\hline \multirow[t]{2}{*}{ GDP growth, 2nd lag } & $0.332^{* * *}$ & $0.324^{* * *}$ & $0.324^{* * *}$ & $0.330^{* * *}$ \\
\hline & $(0.06)$ & $(0.06)$ & $(0.06)$ & $(0.06)$ \\
\hline \multirow[t]{2}{*}{ Chg. in pol. rate, 1 st lag } & -0.802 & -0.727 & -0.755 & -0.746 \\
\hline & $(0.81)$ & $(0.80)$ & $(0.82)$ & $(0.78)$ \\
\hline MAPP, 1st lag & & $\begin{array}{r}-0.252^{*} \\
(0.14)\end{array}$ & & \\
\hline MAPPH, 1st lag & & & $\begin{array}{c}-0.288 \\
(0.19)\end{array}$ & \\
\hline MAPPNH, 1st lag & & & & $\begin{array}{r}-0.416^{*} \\
(0.23)\end{array}$ \\
\hline Observations & 1937 & 1937 & 1937 & 1937 \\
\hline No. of countries & 37 & 37 & 37 & 37 \\
\hline
\end{tabular}

Note: Robust standard errors clustered by country are in parentheses. ${ }^{*} \mathrm{p}<0.1,{ }^{* *} \mathrm{p}<0.05, * * * \mathrm{p}<0.01$. MAPP is the overall cumulative macroprudential policy index that sums housing-related and nonhousing measures. MAPPH is the cumulative housing-related macroprudential policy index. MAPPNH is the cumulative nonhousing-related macroprudential policy index. 
Table 12: Panel Estimation Results: Total Credit, 2000:Q1 to 2013:Q4

\begin{tabular}{lrrrr} 
& Baseline & With MAPP & With MAPPH & With MAPPNH \\
\hline L.Real Total Cred. Growth & $0.261^{* * *}$ & $0.259^{* * *}$ & $0.259^{* * *}$ & $0.260^{* * *}$ \\
& $(0.05)$ & $(0.05)$ & $(0.05)$ & $(0.05)$ \\
VIX (log) & 0.887 & 0.795 & 0.780 & 0.886 \\
& $(0.76)$ & $(0.76)$ & $(0.76)$ & $(0.75)$ \\
GDP growth, 1st lag & $0.212^{* * *}$ & $0.203^{* * *}$ & $0.203^{* * *}$ & $0.210^{* * *}$ \\
& $(0.05)$ & $(0.05)$ & $(0.05)$ & $(0.05)$ \\
GDP growth, 2nd lag & $0.326^{* * *}$ & $0.318^{* * *}$ & $0.318^{* * *}$ & $0.324^{* * *}$ \\
& $(0.07)$ & $(0.07)$ & $(0.07)$ & $(0.07)$ \\
Chg. in pol. rate, 1st lag & -0.500 & -0.425 & -0.443 & -0.453 \\
& $(0.78)$ & $(0.78)$ & $(0.80)$ & $(0.77)$ \\
\hline MAPP, 1st lag & & -0.206 & & \\
& & $(0.16)$ & & -0.239 \\
MAPPH, 1st lag & & & $(0.20)$ & \\
& & & & -0.314 \\
MAPPNH, 1st lag & & & & $0.30)$ \\
\hline Observations & 1939 & 1939 & 1939 & 1939 \\
No. of countries & 37 & 37 & 37 & 37 \\
\hline
\end{tabular}

Note: Robust standard errors clustered by country are in parentheses. ${ }^{*} \mathrm{p}<0.1,{ }^{* *} \mathrm{p}<0.05, * * * \mathrm{p}<0.01$. MAPP is the overall cumulative macroprudential policy index that sums housing-related and nonhousing measures. MAPPH is the cumulative housing-related macroprudential policy index. MAPPNH is the cumulative nonhousing-related macroprudential policy index. 
Table 13: Subsample Panel Estimation Results: Bank Credit, 2000:Q1 to 2013:Q4

\begin{tabular}{|c|c|c|c|c|c|c|}
\hline & $\mathrm{AE}$ & EME & $\mathrm{AE}$ & EME & $\mathrm{AE}$ & EME \\
\hline \multirow[t]{2}{*}{ L.Real Cred. Growth } & $0.379^{* * *}$ & $0.318^{* * *}$ & $0.380^{* * *}$ & $0.322^{* * *}$ & $0.389^{* * *}$ & $0.316^{* * *}$ \\
\hline & $(0.07)$ & $(0.05)$ & $(0.07)$ & $(0.05)$ & $(0.07)$ & $(0.05)$ \\
\hline \multirow[t]{2}{*}{ VIX (log) } & $-1.746^{* *}$ & -1.690 & $-1.720 * *$ & -1.727 & $-1.640 * *$ & -1.452 \\
\hline & $(0.82)$ & $(1.30)$ & $(0.81)$ & $(1.31)$ & $(0.81)$ & $(1.30)$ \\
\hline \multirow[t]{2}{*}{ GDP growth, 1st lag } & $0.214^{* * *}$ & $0.255^{* * *}$ & $0.213^{* * *}$ & $0.260 * * *$ & $0.227 * * *$ & $0.257 * * *$ \\
\hline & $(0.06)$ & $(0.07)$ & $(0.06)$ & $(0.07)$ & $(0.07)$ & $(0.07)$ \\
\hline \multirow[t]{2}{*}{ GDP growth, 2nd lag } & $0.296^{* * *}$ & $0.278^{* * *}$ & $0.295^{* * *}$ & $0.283^{* * *}$ & $0.308^{* * *}$ & $0.280 * * *$ \\
\hline & $(0.09)$ & $(0.05)$ & $(0.09)$ & $(0.05)$ & $(0.09)$ & $(0.05)$ \\
\hline \multirow[t]{2}{*}{ Chg. in pol. rate, 1 st lag } & -1.147 & -0.960 & -1.145 & -1.015 & $-1.252^{*}$ & -0.922 \\
\hline & $(0.74)$ & $(0.73)$ & $(0.75)$ & $(0.74)$ & $(0.76)$ & $(0.72)$ \\
\hline MAPP, 1st lag & $\begin{array}{r}-0.490^{*} \\
(0.29)\end{array}$ & $\begin{array}{r}-0.401^{* *} \\
(0.18)\end{array}$ & & & & \\
\hline MAPPH, 1st lag & & & $\begin{array}{r}-0.479^{*} \\
(0.29)\end{array}$ & $\begin{array}{r}-0.334 \\
(0.24)\end{array}$ & & \\
\hline MAPPNH, 1st lag & & & & & $\begin{array}{r}-0.660 \\
(0.94)\end{array}$ & $\begin{array}{r}-0.986^{* * *} \\
(0.38)\end{array}$ \\
\hline Observations & 1143 & 1585 & 1143 & 1585 & 1143 & 1585 \\
\hline No. of countries & 22 & 33 & 22 & 33 & 22 & 33 \\
\hline
\end{tabular}

Note: Robust standard errors clustered by country are in parentheses. AE=Advanced economies, EME=Emerging market economies. ${ }^{*} \mathrm{p}<0.1,{ }^{* *} \mathrm{p}<0.05,{ }^{* * *} \mathrm{p}<0.01$. MAPP is the overall cumulative macroprudential policy index that sums housingrelated and nonhousing measures. MAPPH is the cumulative housing-related macroprudential policy index. MAPPNH is the cumulative nonhousing-related macroprudential policy index. 
Table 14: Subsample Panel Estimation Results: Housing Credit, 2000:Q1 to 2013:Q4

\begin{tabular}{|c|c|c|c|c|c|c|}
\hline & $\mathrm{AE}$ & EME & $\mathrm{AE}$ & EME & $\mathrm{AE}$ & EME \\
\hline L.Real Housing Cred. Growth & 0.140 & $0.587^{* * *}$ & 0.139 & $0.582^{* * *}$ & 0.155 & $0.594^{* * *}$ \\
\hline & $(0.13)$ & $(0.06)$ & $(0.13)$ & $(0.06)$ & $(0.13)$ & $(0.06)$ \\
\hline VIX $(\log )$ & $\begin{array}{r}-3.009^{* * *} \\
(1.44)\end{array}$ & $\begin{array}{r}-2.292^{*} \\
(1.28)\end{array}$ & $\begin{array}{r}-2.972^{* *} \\
(1.42)\end{array}$ & $\begin{array}{r}-2.429^{*} \\
(1.25)\end{array}$ & $\begin{array}{r}-2.706^{*} \\
(1.41)\end{array}$ & $\begin{array}{r}-1.900 \\
(1.29)\end{array}$ \\
\hline GDP growth, 1st lag & $\begin{array}{r}0.325^{* * * *} \\
(0.11)\end{array}$ & $\begin{array}{r}0.166^{* *} \\
(0.08)\end{array}$ & $\begin{array}{r}0.323^{* * *} \\
(0.11)\end{array}$ & $\begin{array}{r}0.166^{* *} \\
(0.07)\end{array}$ & $\begin{array}{r}0.346^{* * *} \\
(0.11)\end{array}$ & $\begin{array}{r}0.180^{* *} \\
(0.08)\end{array}$ \\
\hline GDP growth, 2nd lag & $\begin{array}{r}0.303^{* * *} \\
(0.09)\end{array}$ & $\begin{array}{r}0.100 \\
(0.07)\end{array}$ & $\begin{array}{r}0.300^{* * * *} \\
(0.09)\end{array}$ & $\begin{array}{r}0.101 \\
(0.07)\end{array}$ & $\begin{array}{r}0.325^{* * *} \\
(0.08)\end{array}$ & $\begin{array}{r}0.106 \\
(0.08)\end{array}$ \\
\hline Chg. in pol. rate, 1 st lag & $\begin{array}{r}-3.170 * * * \\
(1.09)\end{array}$ & $\begin{array}{r}0.999^{*} \\
(0.56)\end{array}$ & $\begin{array}{r}-3.149^{* * *} \\
(1.07)\end{array}$ & $\begin{array}{r}0.973^{*} \\
(0.57)\end{array}$ & $\begin{array}{r}-3.308^{* * *} \\
(1.05)\end{array}$ & $\begin{array}{r}0.888 \\
(0.59)\end{array}$ \\
\hline MAPP, 1st lag & $\begin{array}{r}-1.034^{*} \\
(0.59)\end{array}$ & $\begin{array}{r}-0.563^{*} \\
(0.29)\end{array}$ & & & & \\
\hline MAPPH, 1st lag & & & $\begin{array}{r}-1.095^{*} \\
(0.64)\end{array}$ & $\begin{array}{r}-0.934^{* * *} \\
(0.35)\end{array}$ & & \\
\hline MAPPNH, 1st lag & & & & & $\begin{array}{r}0.555 \\
(2.72) \\
\end{array}$ & $\begin{array}{r}-0.020 \\
(0.83)\end{array}$ \\
\hline Observatiol & 1142 & 1240 & 1142 & 1240 & 1142 & 1240 \\
\hline No. of countries & 22 & 31 & 22 & 31 & 22 & 31 \\
\hline
\end{tabular}

Note: Robust standard errors clustered by country are in parentheses. AE=Advanced economies, EME=Emerging market economies. ${ }^{*} \mathrm{p}<0.1,{ }^{* *} \mathrm{p}<0.05,{ }^{* * *} \mathrm{p}<0.01$. MAPP is the overall cumulative macroprudential policy index that sums housingrelated and nonhousing measures. MAPPH is the cumulative housing-related macroprudential policy index. MAPPNH is the cumulative nonhousing-related macroprudential policy index. 
Table 15: Subsample Panel Estimation Results: House Prices, 2000:Q1 to 2013:Q4

\begin{tabular}{|c|c|c|c|c|c|c|}
\hline & $\mathrm{AE}$ & EME & $\mathrm{AE}$ & EME & $\mathrm{AE}$ & EME \\
\hline L.Real House Price Growth & $0.312^{* *}$ & $0.163^{*}$ & $0.313^{* *}$ & $0.161^{*}$ & $0.323^{* *}$ & $0.163^{*}$ \\
\hline VIX (log) & $\begin{array}{r}(0.13) \\
-3.350 * * *\end{array}$ & $\begin{array}{r}(0.09) \\
-5235 * * *\end{array}$ & $\begin{array}{r}(0.13) \\
-3.322 * * *\end{array}$ & $\begin{array}{r}(0.09) \\
-5284 * * *\end{array}$ & $\begin{array}{r}(0.13) \\
-3200 * * *\end{array}$ & $\begin{array}{r}(0.09) \\
-5069 * * *\end{array}$ \\
\hline$V I X(\log )$ & $\begin{array}{r}-3.350^{* * *} \\
(0.99)\end{array}$ & $\begin{array}{r}-5.235^{* * *} \\
(1.95)\end{array}$ & $\begin{array}{r}-0.022 \\
(0.98)\end{array}$ & $\begin{array}{r}-5.284 .95) \\
(1.95)\end{array}$ & $\begin{array}{r}-3.2000 .97) \\
(0.97\end{array}$ & $(1.88)$ \\
\hline GDP growth, 1st lag & $\begin{array}{r}0.136^{* *} \\
(0.06)\end{array}$ & $\begin{array}{r}0.359^{* * *} \\
(0.12)\end{array}$ & $\begin{array}{r}0.135^{* *} \\
(0.06)\end{array}$ & $\begin{array}{r}0.361^{* * *} \\
(0.12)\end{array}$ & $\begin{array}{r}0.146^{* *} \\
(0.06)\end{array}$ & $\begin{array}{r}0.370^{* * *} \\
(0.12)\end{array}$ \\
\hline GDP growth, 2nd lag & $\begin{array}{r}0.282^{* * *} \\
(0.11)\end{array}$ & $\begin{array}{r}0.141^{* * *} \\
(0.06)\end{array}$ & $\begin{array}{r}0.280^{* * *} \\
(0.11)\end{array}$ & $\begin{array}{r}0.144^{* * *} \\
(0.06)\end{array}$ & $\begin{array}{r}0.292^{* * *} \\
(0.12)\end{array}$ & $\begin{array}{r}0.147^{* *} \\
(0.06)\end{array}$ \\
\hline Chg. in pol. rate, 1 st lag & $\begin{array}{r}-2.679^{* *} \\
(1.17)\end{array}$ & $\begin{array}{r}-0.513 \\
(0.47)\end{array}$ & $\begin{array}{r}-2.672^{* *} \\
(1.16)\end{array}$ & $\begin{array}{r}-0.523 \\
(0.48)\end{array}$ & $\begin{array}{r}-2.789^{* *} \\
(1.21)\end{array}$ & $\begin{array}{r}-0.569 \\
(0.46)\end{array}$ \\
\hline MAPP, 1st lag & $\begin{array}{r}-0.582^{*} \\
(0.34)\end{array}$ & $\begin{array}{c}-0.313 \\
(0.20)\end{array}$ & & & & \\
\hline MAPPH, 1st lag & & & $\begin{array}{r}-0.574^{*} \\
(0.34)\end{array}$ & $\begin{array}{r}-0.459^{*} \\
(0.27)\end{array}$ & & \\
\hline MAPPNH, 1st lag & & & & & $\begin{array}{r}-0.628 \\
(0.80)\end{array}$ & $\begin{array}{r}-0.180 \\
(0.45)\end{array}$ \\
\hline Observations & 1156 & 1194 & 1156 & 1194 & 1156 & 1194 \\
\hline No. of countries & 23 & 30 & 23 & 30 & 23 & 30 \\
\hline
\end{tabular}

Note: Robust standard errors clustered by country are in parentheses. AE=Advanced economies, EME=Emerging market economies. ${ }^{*} \mathrm{p}<0.1,{ }^{* *} \mathrm{p}<0.05,{ }^{* * *} \mathrm{p}<0.01$. MAPP is the overall cumulative macroprudential policy index that sums housingrelated and nonhousing measures. MAPPH is the cumulative housing-related macroprudential policy index. MAPPNH is the cumulative nonhousing-related macroprudential policy index. 


\section{Appendix A Country Groupings}

Advanced Economies: Australia, Austria, Belgium, Canada, Denmark, Finland, France, Germany, Greece, Iceland, Ireland, Italy, Japan, Luxembourg, Malta, Netherlands, New Zealand, Norway, Portugal, Spain, Sweden, Switzerland, United Kingdom.

Emerging Economies: Asia (China, Hong Kong, India, Indonesia, Korea, Malaysia, Philippines, Singapore, Taiwan, Thailand); Latin America (Argentina, Brazil, Chile, Colombia, Mexico, Peru, Uruguay); CEE (Bulgaria, Croatia, Czech Republic, Estonia, Hungary, Latvia, Lithuania, Poland, Romania, Russia, Slovakia, Slovenia, Serbia, Ukraine); Others (Israel, South Africa, Turkey).

\section{Appendix B Macroprudential Dataset}

Tables B1 and B2 display our coding of policy measures in the 57 countries for each quarter from the first quarter of 2000 to the last quarter of 2013 for housing and nonhousing measures, respectively. Table B1 demonstrates that housing measures have been used actively by many countries, particularly since 2007. Asian and Eastern European countries used such measures most frequently, and often adjusted LTV caps, DTI caps, and risk weights on housing loans several times over the sample period. During the financial crisis many countries relaxed their macroprudential stance on mortgage lending. We do not observe as many nonhousing measures in table B2, but these measures were nonetheless used by nearly half the countries in our sample at some point from 2000 to 2013. Nonhousing measures were also adjusted by many countries that used them, especially during the financial crisis, and tightenings were much more common than easings across all measures. The most popular nonhousing measures were capital requirements and loan-loss provisioning requirements, while consumer loan measures and credit growth limits were used more sparingly.

\section{Appendix C Dataset for Other Variables}

Finding data on credit and house prices for 57 countries with a relatively consistent definition is a difficult task, particularly for the emerging markets in our sample. For some countries, data is unavailable for the beginning of the sample period. Definitions and reporting methodologies vary across countries. This section provides a brief discussion of our selection criteria for the dependent variables used in our panel data analysis and event studies.

Our data on bank credit comes primarily from the Bank for International Settlements (BIS) dataset on credit to the private sector. The series we use is credit from domestic banks to 
the non-financial private sector. We chose to study domestic credit because macroprudential policies govern domestic banks. Since this public database does not cover all countries in our sample, we supplement the BIS data with data from national sources supplied by Haver Analytics, again using domestic credit to the private sector, although the definition may vary across countries. Table C3 describes the exact definition and source for each country.

Housing credit is the most difficult to locate out of the three dependent variables. We collect the same data used in Kuttner and Shim (2013) for housing credit, using BIS databases, central bank websites, and the commercial sources Datastream and CEIC. This data should be understood as a subset of total bank credit; that is, we select the series that is closest to domestic bank credit to households for home purchase for each country. Table C4 describes the definition and source for each country.

Our house price data also comes from the BIS for most countries and is supplemented with data from national sources when necessary. Many countries have a variety of different house price indexes covering different types of homes and geographic locations. Since macroprudential regulations are generally issued on a national level and typically cover all types of residential properties, we select the broadest house price index available, ideally one covering the entire geographic area of the country and both new and existing homes. Table C5 describes the exact definition and source for each country.

The real gross domestic product data comes from national sources collected by Haver Analytics. We use the national source's seasonally adjusted series where available, and use the U.S. Census Bureau's X12-ARIMA Seasonal Adjustment program on national sources for countries that do not seasonally adjust their own GDP series.

The VIX index is an index of implied volatility of S\&P500 index options. The data comes from Bloomberg.

For monetary policy, we use each country's official policy rate. To convert the data to quarterly frequency we average the policy rate at the end of each of the three months in that quarter. The data comes from Bloomberg, CEIC, and Haver. 
Table B1: Macroprudential Policies: Housing

\begin{tabular}{|c|c|c|c|c|c|}
\hline & 1. Loan-to-Value Cap & 2. Debt-to-Income Cap & $\begin{array}{l}\text { 3. Other Housing Measures Excl. } \\
\text { CCR and Prov. }\end{array}$ & $\begin{array}{l}\text { 4. Countercyclical Capital } \\
\text { Requirements (Housing Related) }\end{array}$ & $\begin{array}{l}\text { 5. Loan-Loss Provisioning } \\
\text { (Housing Related) }\end{array}$ \\
\hline 2000-Q1 & Colombia (1), Hong Kong (2) & Colombia (1), Hong Kong (2) & $\begin{array}{l}\text { Norway (1), Portugal (1), South } \\
\text { Africa (1) }\end{array}$ & $\begin{array}{l}\text { Norway (1), Portugal (1), South } \\
\text { Africa (1) }\end{array}$ & \\
\hline \multicolumn{6}{|l|}{$2000-Q 2$} \\
\hline 2000-Q3 & Hong Kong (-1) & & Philippines (1) & & \\
\hline \multicolumn{6}{|l|}{ 2000-Q4 } \\
\hline \multicolumn{6}{|l|}{ 2001-Q1 } \\
\hline 2001-Q2 & & & & Norway (-1) & \\
\hline 2001-Q3 & Iceland (-1) & & Singapore (1) & & \\
\hline 2001-Q4 & Hong Kong (-1) & & & & \\
\hline \multicolumn{6}{|c|}{ 2002-Q1 } \\
\hline \multicolumn{6}{|l|}{ 2002-Q2 } \\
\hline 2002-Q3 & Korea (1), Philippines (-1) & & & & \\
\hline 2002-Q4 & & & & Korea (1) & \\
\hline \multicolumn{6}{|l|}{ 2003-Q1 } \\
\hline 2003-Q2 & Denmark (1), Korea (1) & & Denmark (1) & Argentina (1) & \\
\hline \multicolumn{6}{|l|}{ 2003-Q3 } \\
\hline 2003-Q4 & Korea (1), Thailand (1) & & Denmark (-1) & & \\
\hline 2004-Q1 & Korea (-1), Romania(1) & Romania (1) & Canada (-1), Hungary (1) & Argentina (2) & \\
\hline \multicolumn{6}{|c|}{ 2004-Q2 } \\
\hline 2004-Q3 & China (1), Sweden (1) & China (1) & & & \\
\hline 2004-Q4 & Iceland (-1), Serbia (1) & Serbia (2) & Estonia (1), Serbia (1) & Australia (1), India (1) & \\
\hline 2005-Q1 & China (1) & & & & \\
\hline 2005-Q2 & Bulgaria (1) & & & Bulgaria (1), Malaysia (1) & \\
\hline 2005-Q3 & Korea (1), Singapore (-1) & Korea (1), Romania (1) & & & \\
\hline 2005-Q4 & & Greece (1) & & & Greece (1) \\
\hline 2006-Q1 & & & Canada (-1) & Estonia (1) & \\
\hline 2006-Q2 & Bulgaria (1), China (1) & Korea (1) & & Ireland (1) & \\
\hline 2006-Q3 & Argentina (-1), Iceland (1) & & & Uruguay (1) & \\
\hline 2006-Q4 & Croatia (1), Korea (1) & Croatia (1), Korea (1) & & & \\
\hline 2007-Q1 & Iceland (-1) & Korea (1), Netherlands (1) & Netherlands (1) & France (1), Italy (1), Lithuania (1) & \\
\hline \multicolumn{6}{|l|}{ 2007-Q2 } \\
\hline 2007-Q3 & \begin{tabular}{|l|} 
Canada (-1), China (1), Denmark \\
$(1)$, Latvia (1)
\end{tabular} & Korea (1), Latvia (1) & Brazil (1) & & \\
\hline \multicolumn{6}{|c|}{\begin{tabular}{|l|l|l|l|l|l|l|}
$2007-Q 4$ & \\
\end{tabular}} \\
\hline 2008-Q1 & & Latvia (1) & Philippines (-1) & $\begin{array}{l}\text { Estonia (-1), Latvia (-1), Poland } \\
(1)\end{array}$ & \\
\hline 2008-Q2 & Iceland (-1) & & & Spain (1) & \\
\hline 2008-Q3 & Serbia (1) & & & Serbia (1) & \\
\hline 2008-Q4 & $\begin{array}{l}\text { Canada (1), China (-1), Korea (- } \\
\text { 1), Luxembourg (-1) }\end{array}$ & Canada (1), Korea (-1) & & & \\
\hline 2009-Q1 & Serbia (-1) & & $\begin{array}{l}\text { Switzerland (1), United Kingdom } \\
\text { (1) }\end{array}$ & Estonia (-1), Latvia $(-1)$ & Switzerland (1) \\
\hline 2009-Q2 & Thailand (-1) & & & & \\
\hline 2009-Q3 & $\begin{array}{l}\text { Chile (-1), Denmark (-1), Korea } \\
\text { (1) }\end{array}$ & Korea (1) & Singapore (1) & & \\
\hline 2009-Q4 & Hong Kong (1), Korea (1) & & Hong Kong (1), Iceland (-1) & & \\
\hline 2010-Q1 & $\begin{array}{l}\text { Finland (1), Hungary (1), } \\
\text { Netherlands (1), Norway (2), } \\
\text { Singapore (1) }\end{array}$ & Hungary (1), Norway (2) & $\begin{array}{l}\text { Australia (1), Finland (1), } \\
\text { Malaysia (1), Singapore (1) }\end{array}$ & Bulgaria (-1) & \\
\hline 2010-Q2 & Canada (2), China (1) & Serbia (-1) & Canada (1), China (1) & & \\
\hline 2010-Q3 & $\begin{array}{l}\text { China (1), Hong Kong (1), } \\
\text { Singapore (1) }\end{array}$ & Hong Kong (1), Korea (-1) & $\begin{array}{l}\text { China (1), Hong Kong (1), } \\
\text { Hungary (2), Singapore (1) }\end{array}$ & & Israel (1) \\
\hline 2010-Q4 & $\begin{array}{l}\text { Hong Kong (1), India (1), } \\
\text { Malaysia (1), Sweden (1), Taiwan } \\
\text { (1) }\end{array}$ & Poland (1) & Hong Kong (1) & India (1), Israel (1), Thailand (1) & India (1) \\
\hline 2011-Q1 & $\begin{array}{l}\text { Canada (1), China (2), Poland (1), } \\
\text { Romania (1), Singapore (1), } \\
\text { Turkey (1) }\end{array}$ & & $\begin{array}{l}\text { Canada (2), China (1), Israel (1), } \\
\text { Mexico (1), Singapore (1) }\end{array}$ & Malaysia (1), Thailand (1) & \\
\hline 2011-Q2 & Hong Kong (3), Serbia (2) & Korea (1) & $\begin{array}{l}\text { Hungary (-1), Israel (1), Serbia } \\
\text { (1), Taiwan (1) }\end{array}$ & & \\
\hline 2011-Q3 & Netherlands (1) & & Netherlands (1) & & \\
\hline 2011-Q4 & Malaysia (1), Norway (2) & Poland (1) & India (1), Singapore (1) & & \\
\hline 2012-Q1 & & & Malaysia (1), & Thailand (1) & \\
\hline 2012-Q2 & Indonesia (1), Korea (-1) & Korea $(-1)$ & & & \\
\hline 2012-Q3 & Canada (1), Hong Kong (1) & Canada (1), Hong Kong (1) & $\begin{array}{l}\text { Canada (2), Hong Kong (1), } \\
\text { United Kingdom (-1) }\end{array}$ & Israel (1) & \\
\hline 2012-Q4 & $\begin{array}{l}\text { Canada (1), Israel (2), Serbia (1), } \\
\text { Singapore (1) }\end{array}$ & Serbia $(-1)$ & Hong Kong (1) & Peru (1), Serbia (-1) & \\
\hline 2013-Q1 & $\begin{array}{l}\text { China (1), Hong Kong (1), } \\
\text { Netherlands (1), Poland (1), } \\
\text { Singapore (1) }\end{array}$ & Hong Kong (1), Singapore (1) & $\begin{array}{l}\text { China (1), Malaysia (1), } \\
\text { Singapore (1) }\end{array}$ & $\begin{array}{l}\text { Hong Kong (1), Israel (1), } \\
\text { Switzerland (2) }\end{array}$ & Israel (1) \\
\hline 2013-Q2 & India (1) & Singapore (1) & & Sweden (1) & \\
\hline 2013-Q3 & Indonesia (1) & Israel (1) & Israel (1) & Israel (1) & \\
\hline 2013-Q4 & China (1) & & New Zealand (1) & & \\
\hline 2014-Q1 & Netherlands (1) & $\begin{array}{l}\text { Switzerland (1), Taiwan (1), } \\
\text { United Kingdom (1) }\end{array}$ & Switzerland (1) & & \\
\hline 2014-Q2 & & & & & \\
\hline
\end{tabular}


Table B2: Macroprudential Policies: Non-Housing

\begin{tabular}{|c|c|c|c|c|}
\hline & $\begin{array}{l}\text { 1. Countercyclical Capital } \\
\text { Requirements }\end{array}$ & 2. Loan-Loss Provisioning & 3. Consumer Loan Measures & 4. Credit Growth Limits \\
\hline 2000-Q1 & & & & Greece (1) \\
\hline 2000-Q2 & & Philippines (1) & & Greece $(-1)$ \\
\hline $2000-Q 3$ & & Peru (1), Spain (1) & & \\
\hline \multicolumn{5}{|l|}{ 2000-Q4 } \\
\hline 2001-Q1 & Mexico (1) & & & \\
\hline \multicolumn{5}{|l|}{ 2001-Q2 } \\
\hline 2001-Q3 & & Uruguay (1) & & \\
\hline 2001-Q4 & & Philippines (-1) & & \\
\hline \multicolumn{5}{|l|}{ 2002-Q1 } \\
\hline \multicolumn{5}{|l|}{ 2002-Q2 } \\
\hline \multicolumn{5}{|l|}{$2002-Q 3$} \\
\hline 2002-Q4 & & Korea (1) & & \\
\hline 2003-Q1 & & & & Croatia (2) \\
\hline 2003-Q2 & Argentina (1) & & & \\
\hline \multicolumn{5}{|c|}{$2003-Q 3$} \\
\hline 2003-Q4 & & & & Croatia (-1) \\
\hline 2004-Q1 & & Croatia (1), Spain (1) & Romania (1) & \\
\hline 2004-Q2 & Argentina $(-1)$ & & Thailand (1) & \\
\hline \multicolumn{5}{|c|}{ 2004-Q3 } \\
\hline 2004-Q4 & Argentina (1) & & & \\
\hline 2005-Q1 & & Greece (-1) & Thailand (1) & \\
\hline 2005-Q2 & & & & Bulgaria (1) \\
\hline 2005-Q3 & India (1) & Romania (1) & & Romania (1) \\
\hline 2005-Q4 & & $\begin{array}{l}\text { Bulgaria (1), China (1), Greece } \\
\text { (1), India (1) }\end{array}$ & & \\
\hline 2006-Q1 & Serbia (1) & & & Bulgaria (1) \\
\hline 2006-Q2 & Bulgaria (1), Croatia (1), India (1) & Croatia (1), India (1) & & \\
\hline 2006-Q3 & Serbia (1) & Peru (1), Uruguay (1) & & Serbia (1) \\
\hline 2006-Q4 & & Korea (1) & & \\
\hline 2007-Q1 & Latvia $(-1)$ & India (1), Ukraine (1) & & $\begin{array}{l}\text { Croatia (1), Romania (-1), Serbia } \\
\text { (1) }\end{array}$ \\
\hline $2007-Q 2$ & Turkey (1) & Colombia (1) & Thailand (1) & \\
\hline 2007-Q3 & Brazil (1) & & & \\
\hline \multicolumn{5}{|c|}{\begin{tabular}{|l|l} 
2007-Q4 & Argentina (-1), Slovenia (1) \\
\end{tabular}} \\
\hline 2008-Q1 & $\begin{array}{l}\text { Croatia (2), Latvia (-1), Romania } \\
\text { (1), Turkey (2) }\end{array}$ & Romania (1) & & \\
\hline 2008-Q2 & & Colombia (1) & & \\
\hline 2008-Q3 & & Serbia (1) & & \\
\hline 2008-Q4 & Colombia (1), India (-1) & India (-1), Peru (1), Spain (-1) & & Serbia $(-1)$ \\
\hline 2009-Q1 & & $\begin{array}{l}\text { Bulgaria (-1), Croatia (-1), } \\
\text { Switzerland (1) }\end{array}$ & & Serbia $(-1)$ \\
\hline 2009-Q2 & & & & Serbia $(-1)$ \\
\hline 2009-Q3 & Romania (-1) & Mexico (1), Russia (-1) & & \\
\hline $2009-Q 4$ & & & & Croatia (-1) \\
\hline 2010-Q1 & Bulgaria (-1), Russia (1) & & Hungary (1) & \\
\hline 2010-Q2 & & & Turkey (1) & Turkey (1) \\
\hline 2010-Q3 & China (1) & China (1), Israel (1) & & \\
\hline $2010-Q 4$ & Brazil (2) & India (1), Spain (1) & Brazil (1) & \\
\hline 2011-Q1 & Malaysia (1) & Mexico (1) & & \\
\hline 2011-Q2 & Turkey (1) & Turkey (1) & Turkey (1) & Turkey (1) \\
\hline 2011-Q3 & Peru (1) & & & \\
\hline 2011-Q4 & Brazil (1), Russia (1) & & & \\
\hline 2012-Q1 & Russia (2) & Romania (1) & & \\
\hline 2012-Q2 & Poland (1) & & Indonesia (1) & \\
\hline \multicolumn{5}{|l|}{ 2012-Q3 } \\
\hline \multicolumn{5}{|l|}{ 2012-Q4 } \\
\hline 2013-Q1 & & Israel (1), Russia (1) & Singapore (1) & \\
\hline \multicolumn{5}{|l|}{ 2013-Q2 } \\
\hline 2013-Q3 & Russia (1) & & & \\
\hline 2013-Q4 & & Turkey (1) & Turkey (1) & \\
\hline 2014-Q1 & New Zealand (1), Switzerland (1) & 46 & & \\
\hline 2014-Q2 & & & & \\
\hline
\end{tabular}

Note: The number in parentheses indicates the number of tightenings (positive value) or loosenings (negative value) in each quarter. 


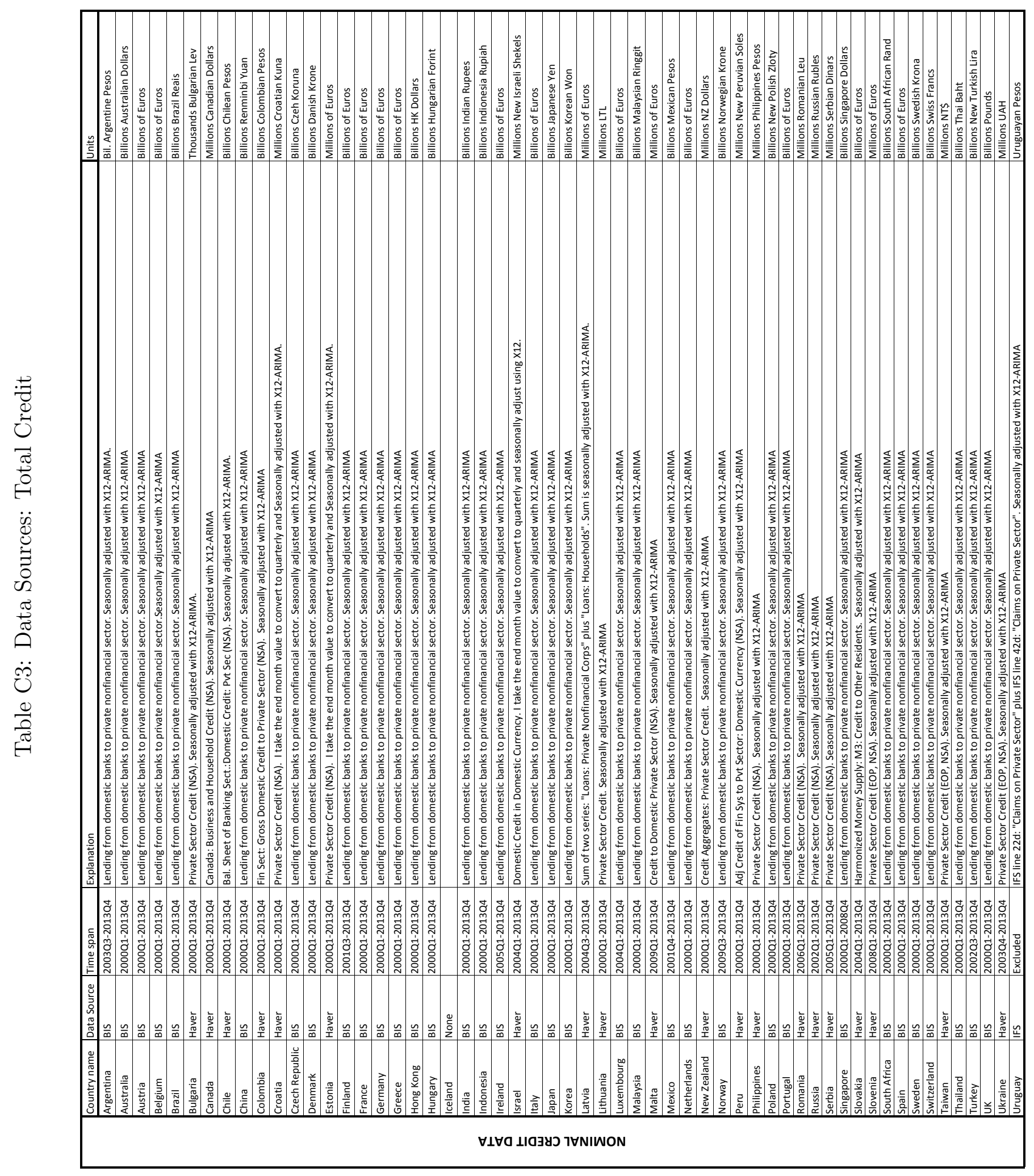




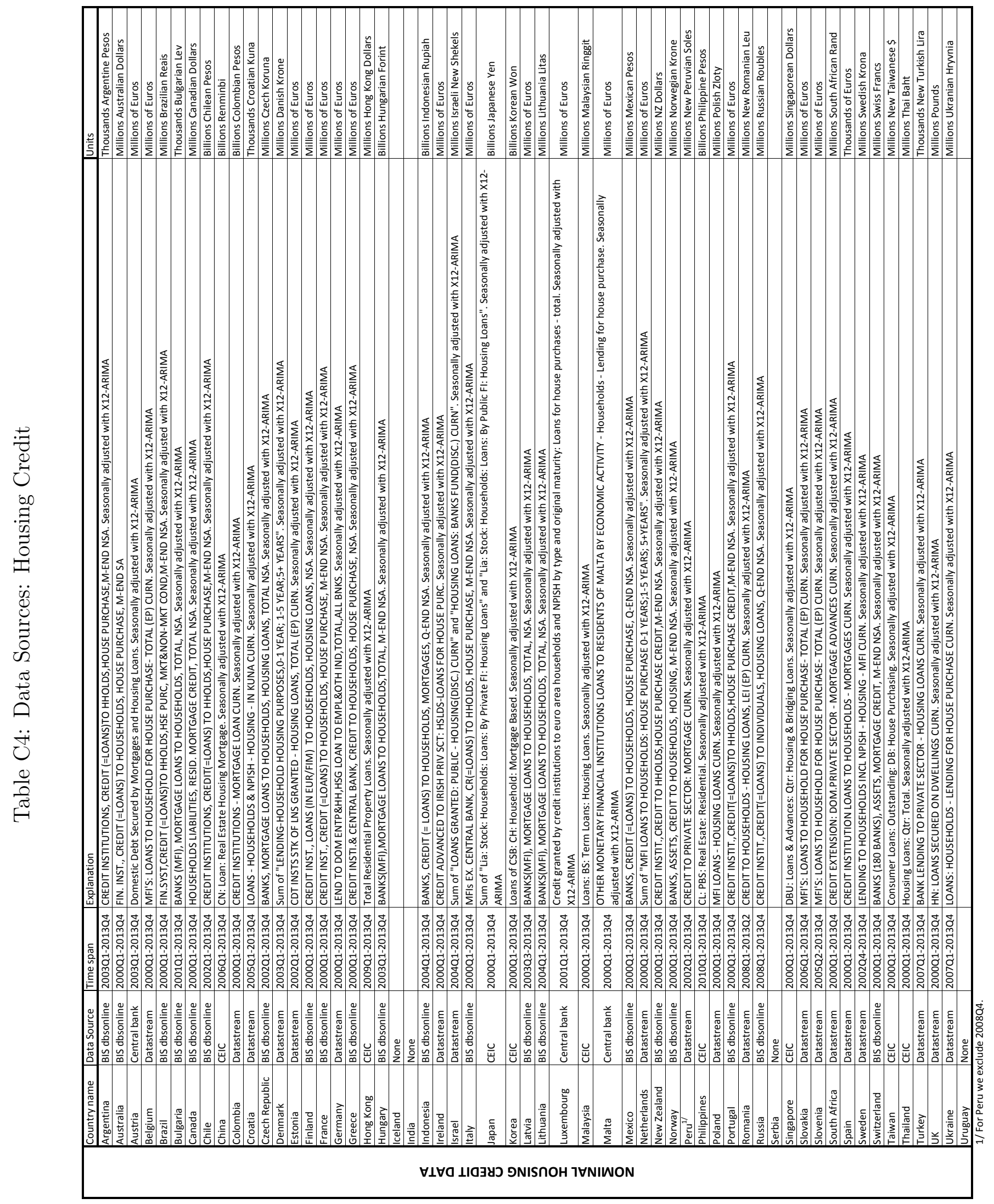




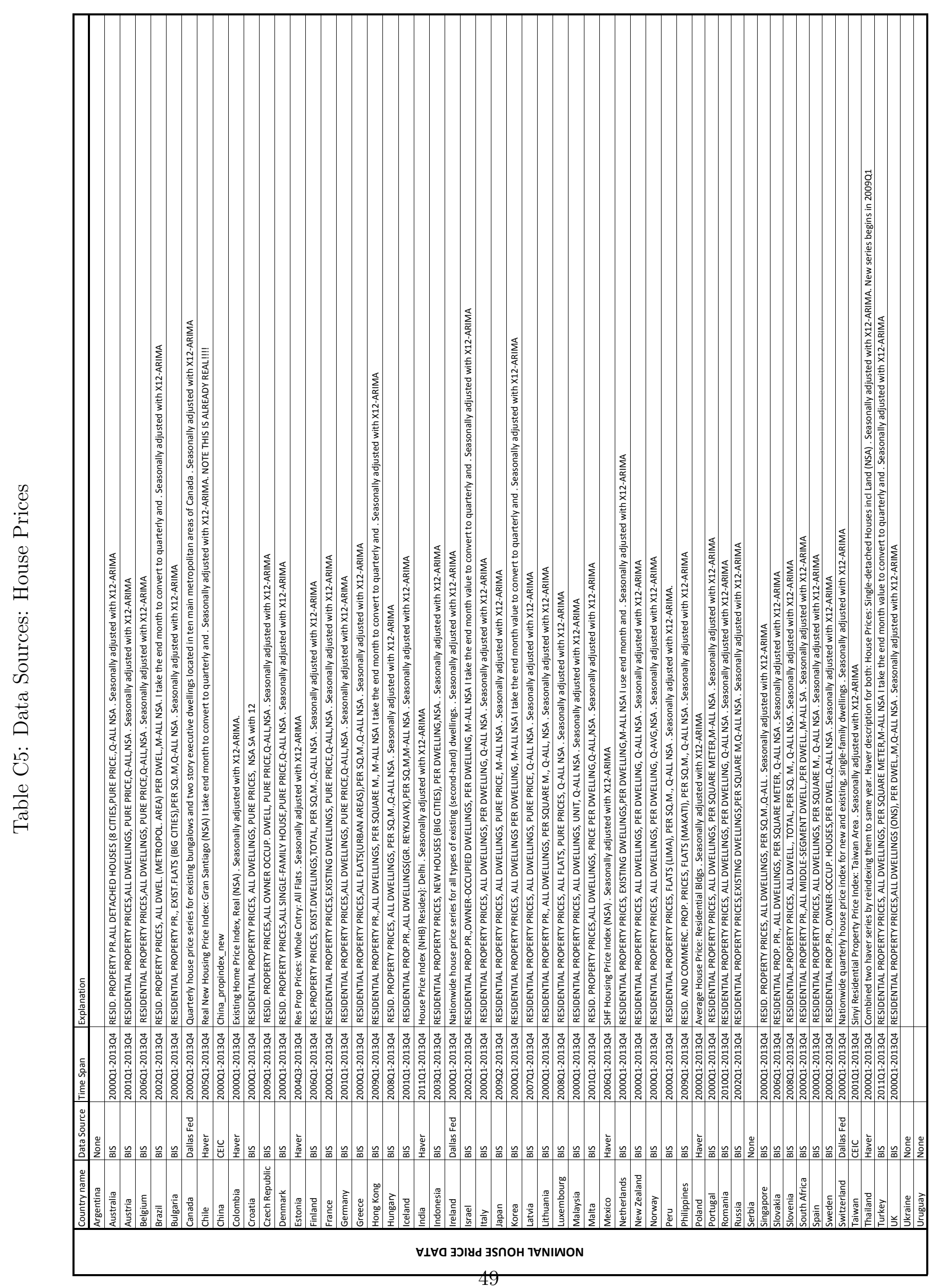

